\title{
Circulation and behavior of euphausiids in two Norwegian sub-Arctic fjords
}

\author{
Meng Zhou ${ }^{1, *}$, Yiwu Zhu ${ }^{1}$, Kurt S. Tande ${ }^{2}$ \\ ${ }^{1}$ Department of Environmental, Coastal and Ocean Sciences, University of Massachusetts Boston, Boston, \\ Massachusetts 02125, USA \\ ${ }^{2}$ Norwegian College of Fishery Science, University of Tromsø, 9037 Tromsø, Norway
}

\begin{abstract}
We conducted 2 cruises in 2 subarctic fjords, Ullsfjorden and Sørfjorden, northern Norway, to investigate the role of coupled advection and individual behavior of euphausiids in determining their distribution and retention. The surveys examined the seasonal change in buoyancy-driven circulation in fjords due to surface cooling and ice formation during the fall and winter, and surface heating, freshwater runoff and a deep-water intrusion during the spring, as well as seasonal variations in euphausiid distribution and migration. The causes leading to vertical migration of euphausiids were studied by light and food measurements. Euphausiid transport was examined on the basis of timing and duration of euphausiid migration, as well as variations in water currents. Our results demonstrate the entrapment of euphausiids in these fjords. To understand the aggregation mechanisms, euphausiid swimming behavior was studied in terms of cruising speed, escape velocity, deterministic swimming and random walking. Existing stochastic aggregation theories were used to interpret the observations of swimming behavior. The mismatch between theories and observations found in this study led us to construct a new model configuration between aggregation, deterministic vs. random swimming, and dispersion.
\end{abstract}

KEY WORDS: Circulation · Advection · Aggregation · Migration · Behavior $\cdot$ Euphausiids Resale or republication not permitted without written consent of the publisher

\section{INTRODUCTION}

Spatial and temporal distribution of zooplankton in oceans, fjords, estuaries and lakes is often complicated by current advection and behavior of zooplankton. Especially in Antarctic and Arctic regions, euphausiids, constituting a key link between primary production and higher trophic levels, exhibit strong aggregation and vertical migration behavior, while current fields are determined by strong tidal currents and mesoscale baroclinic jets and eddies. Determination of these coupled physical and biological processes is necessary to understand local ecosystem functions and develop general models for the behavior of euphausiids, and requires quantitative observations of spatial and temporal distributions of euphausiids and current advection.

The transport and redistribution of zooplankton by mesoscale circulation have been addressed by a number of studies (Haury 1984, Lindahl \& Hernroth 1988, Aksnes et al. 1989, Mackas et al. 1991, Huntley et al.
1995, Zhou 1998b). Common phenomena are advection of zooplankton by coastal currents or jets, and entrapment of zooplankton in convergent eddies. In fjords and estuaries, advection by tidal and residual currents leads to more complicated tidal period distribution and transport of zooplankton (Lindahl \& Hernroth 1988, Aksnes et al. 1989, Gupta et al. 1994). Freshwater runoff can lead to a net surface flux outward and a bottom intrusion nonlinearly coupled with periodic tidal currents (Kaartvedt \& Svendsen 1995, Zhou 1998a). Such semidiurnal or diurnal advection processes of tidal currents may coincide with diel zooplankton behavior.

The diel vertical migration of zooplankton is a common phenomenon in aquatic systems (Cushing 1951, Ohman et al. 1983, Ashjian et al. 1998). Although the underlying cues and causes driving the vertical migration are still debatable, recent studies have shown that zooplankton migrate in direct response to light with maximum upward migration speed at sunset and maximum downward migration speed at sunrise 
(Ringelberg et al. 1991, Ashjian et al. 1998). In a vertical-shear current, a combination of active vertical migration and differential current advection determine the transport and fate of zooplankton.

Aggregation behavior confers advantages in avoiding predation and in utilizing food resources (Partridge 1982, Brooks \& Mullin 1983). Antarctic and Arctic euphausiids exhibit distinct aggregation behavior (Hamner et al. 1983, 1989, Zhou et al. 1994). Euphausiids are not passive particles that respond stochastically to advection and diffusion processes. The mechanism of euphausiid diel aggregation patterns and their response to differential advection of a shear flow is not known, but it is important in preventing dispersion.

Subarctic fjords in northern Norway deviate from most subtropical estuaries by their great depth and variations in runoff and ice formation between spring, fall and winter. These fjords are usually characterized by highly abundant euphausiid populations and high fish production (Falk-Petersen \& Hopkins 1981, Tande \& Slagstad 1982, Hopkins et al. 1984). Seasonal variation in circulation patterns and transport of nutrients and biota are important factors determining the carrying capacities of fjord populations. Previous studies have indicated that residual currents and vertical distribution of Calanus finmarchicus and euphausiids determine the direction of their transport at a nearly steady state (Aksnes et al. 1989). Considering diel vertical migration of zooplankton, seasonal residual and tidal currents, the transport of zooplankton by currents is not in a steady state in northern Norwegian fjords. Although these individual physical and biological processes have been well documented, it is not clearly understood how they are related to the high abundance of euphausiids in subarctic fjords. The data herein are results of our studies on the transport of euphausiids by combined currents and migration behavior within tidal periods in the late fall season of 1995 and the spring of 1996 in Ullsfjorden and Sørfjorden, northern Norway.

\section{MATERIALS AND METHODS}

We chose Ullsfjorden and Sørfjorden in northern Norway as our study sites because of their different physical settings (Fig. 1). Ullsfjorden is a typical open fjord with a deep (>200 m) channel, which connects with the continental shelf. Thus, the temperature and salinity of the bottom water are influenced by shelf water, characterized by temperatures $>5.5^{\circ} \mathrm{C}$ and salinity $>34.5$ (Ljøen 1962). The tides are dominated by $\mathrm{M}_{2}$ and $\mathrm{S}_{2}$ constituents. The heights of neap and spring tides are approximately 1 and $2 \mathrm{~m}$, respectively, with the associated tidal currents varying from 10 to $20 \mathrm{~cm}$ $\mathrm{s}^{-1}$, respectively. In contrast, Sørfjorden is almost separated from Ullsfjorden by a $400 \mathrm{~m}$ wide sill with a mean depth of only $8 \mathrm{~m}$. There are 2 basins $>150 \mathrm{~m}$ deep in Sørfjorden. The tidal current at the entrance is strong, approximately $1 \mathrm{~m} \mathrm{~s}^{-1}$, while in the fjord it does not exceed $5 \mathrm{~cm} \mathrm{~s}^{-1}$. The horizontal excursion range of a water parcel advected by tidal currents during a tidal period is approximately $3 \mathrm{~km}$ in Ullsfjorden and $1 \mathrm{~km}$ in Sørfjorden. Baroclinic currents, which play the primary role in 2-way exchanges of water masses, had not been studied in both fjords during the past.

Zooplankton in both Ullsfjorden and Sørfjorden are dominated by 3 groups - copepods, chaetognaths and euphausiids. Of the copepods, Calanus finmarchicus accounts for $90 \%$ of the abundance (Falk-Petersen \& Hopkins 1981, Tande 1982, Hopkins et al. 1984, Falkenhaug et al. 1997). Of the euphausiids (whose body size range is larger than that of copepods), the 3 Thysanoessa species $T$. inermis, $T$. raschii and T. longicaudata are the dominant organisms, accounting for

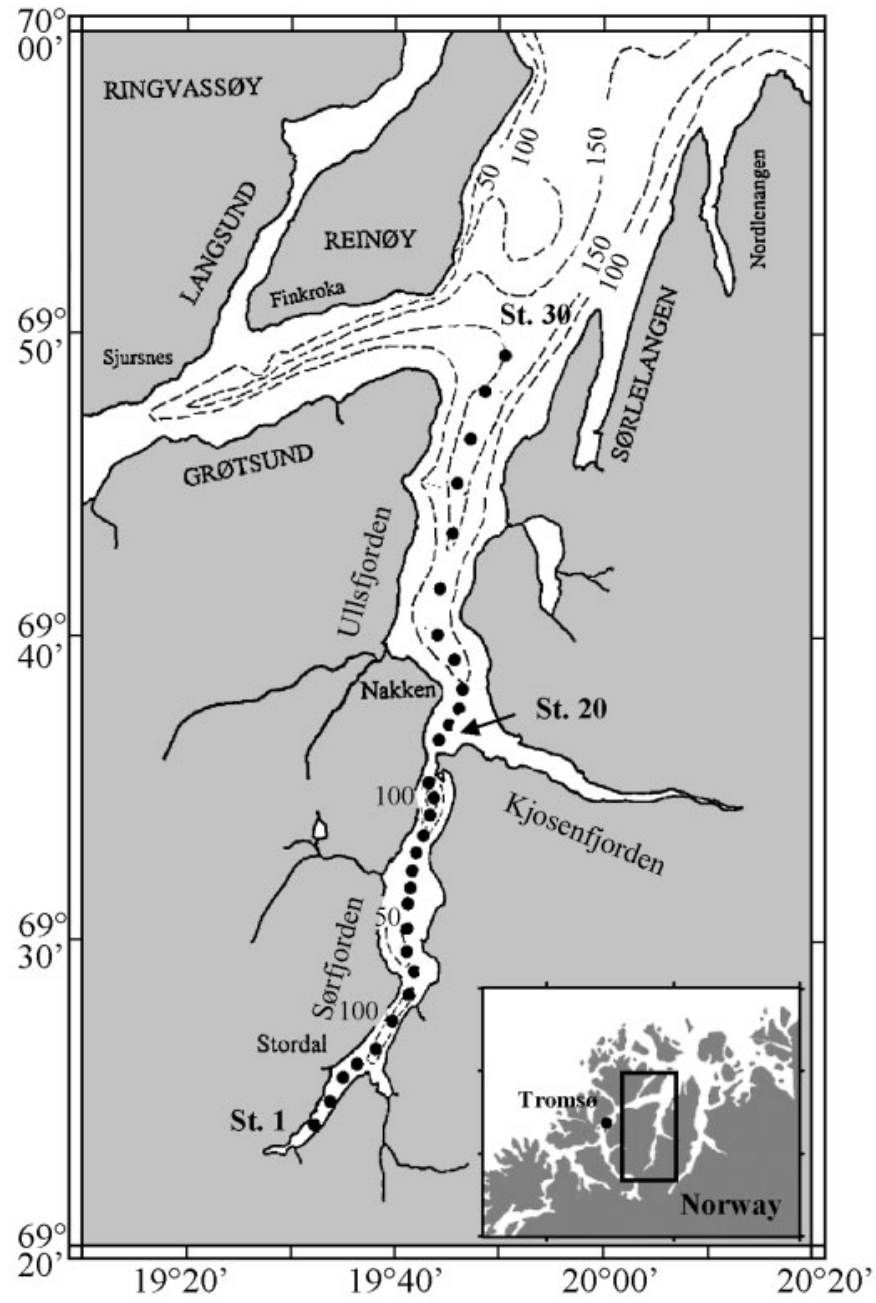

Fig. 1. Bathymetry and location of Ullsfjorden and Sørfjorden, northern Norway 
$>90 \%$ of the total biomass (Falk-Petersen \& Hopkins 1981, Hopkins et al. 1984, Falk-Petersen 1985). Meganyctiphanes norvegica is a shelf and oceanic species, and is usually only found in Ullsfjorden.

Short cruises with RV 'Johan Ruud' and RV 'Jan Mayen' were conducted in the late fall of 1995 and the spring of 1996. In late fall, physical forcing was characterized by atmospheric cooling and limited freshwater runoff with a very short daytime, and in the spring by atmospheric heating and strong freshwater runoff with a very long daytime. The seasonal change in daytime length affects euphausiid behavior, while the variation in freshwater runoff alters the water circulation pattern. These seasonal contrasts provided us with an opportunity to compare the differences in circulation patterns and euphausiid behavior, and their effects on the transport and retention of euphausiids.

The instruments used in this study comprised a vessel mounted (VM), narrow band (NB), acoustic Doppler current profiler (ADCP; RD Instruments) for measuring both current and volume backscattering strength of zooplankton, a CTD (ME MeerestechnikElektronik) for measuring temperature and salinity, a BackScat Fluorometer (Model 1121 MP/Chla; Dr. Haardt) for measuring fluorescence, and a multiple opening - closing net and environmental sensing system (MOCNESS; Wiebe et al. 1976) for taking zooplankton samples. Temperature, salinity and fluorescence were measured at 30 stations along the principal axis of Ullsfjorden and Sørfjorden (Fig. 1). For current measurements, two $153 \mathrm{kHz}$ narrow band ADCPs were mounted on the RV 'Johan Ruud' and RV 'Jan Mayen', individually. Bin length was set at $4 \mathrm{~m}$, pulse length was set equal to bin length, and the blank after transmission was set at $2 \mathrm{~m}$. To ensure accuracy of velocity measurements, a 5 min time average was made, following the instrument specifications, by which the corresponding error was reduced to $1.5 \mathrm{~cm} \mathrm{~s}^{-1}$ in a calm sea (RD Instruments 1989). The error of echo intensity measurements by an $\mathrm{ADCP}$ is $<1 \mathrm{~dB}$ for a single ping.

During the last 2 decades, acoustic technologies and devices have been developed to assess the spatial and temporal distributions of mesozooplankton and micronekton. Vertical migration of zooplankton has been intensively studied using both net tow samples and acoustic surveys (Hopkins et al. 1978, Kalinowski 1978, Zhou et al. 1994, Demer \& Hewitt 1995, Tarling et al. $2001,2002)$; the variation in the acoustic target strength of a single plankter has been studied as a function of its orientation (Demer \& Martin 1995, McGehee et al. 1998, Demer \& Conti 2003); and the aggregation and swarming behavior of krill and micronekton have been studied using acoustic Doppler technology (Zhou \& Huntley 1996, Tarling et al. 2001, Demer et al. 2002, Zhou \& Dorland 2004). Although there are certain errors in the acoustic measurement of mesozooplankton biomass, various studies have clearly indicated a linear correlation between estimates of biovolume from ADCP measurements and those from other sampling devices (Flagg \& Smith 1989a,b, Zhou et al. 1994, Brierley et al. 1998).

To calibrate the backscattering measurements of an ADCP against net tow samples when estimating zooplankton biomass (Flagg \& Smith 1989a,b, Zhou et al. 1994), a series of MOCNESS tows were conducted inside and outside euphausiid swarms. Zooplankton were sampled at depth intervals of 0 to 25,25 to 50,50 to 75,75 to $100 \mathrm{~m}$ and from $100 \mathrm{~m}$ to the bottom with $180 \mu \mathrm{m}$ mesh nets at Stns 1 to 8,17 and 20 in Sørfjorden and Stns 23 to 30 in Ullsfjorden (Fig. 1). Each sample was concentrated and preserved in $10 \%$ formalin buffered with sodium borate. Zooplankton samples were then sorted using a stereomicroscope (Olympus; Model CH30), and the wet volume of euphausiids in each net was measured following standard procedures (Harris et al. 2000).

The Doppler spectrum measurements provided by an ADCP were used to access the swimming velocities of euphausiids. An NB ADCP uses the Doppler frequency reflected from backscatterers in the water column to calculate the velocities, which are used to infer the current velocities (RD Instruments 1989, 1990). During NB ADCP signal processing, the first moment of a power spectrum from the fast Fourier transform (FFT) of received acoustic signals is the Doppler shift, i.e.

$$
\Delta f=\frac{1}{S} \int_{-\infty}^{\infty}\left(f-f_{0}\right) F(f) \mathrm{d} f
$$

where $F(f)$ is the FFT of acoustic signals received by a transducer, $f$ is the frequency, $f_{0}$ is the frequency transmitted by the transducer, $\Delta f$ is the Doppler shift, and $S$ is the zero moment of $F(f)$. The velocity relative to the transducer is equal to $2\left(C \Delta f / f_{0}\right)$, where $C$ is the sound speed, and the factor 2 represents the double Doppler shifts when using 1 transducer as both transmitter and receiver. The second moment of a power spectrum is proportional to the width of the power spectrum, i.e.

$$
\sigma^{2}=\frac{1}{S} \int_{-\infty}^{\infty}(f-\bar{f})^{2} F(f) \mathrm{d} f
$$

where $\sigma$ is the spectrum width, and $\bar{f}$ is the mean frequency of the received acoustic signals. Taking the notation $u=\bar{u}+u^{\prime}$, where $u$ is the velocity of an arbitrary particle in the water volume, $\bar{u}$ is the mean velocity of all backscatterers in a given water volume, and $u$ ' is the difference between $u$ and $\bar{u}$ or the random motion, we have

$$
u^{\prime}=2 C(f-\bar{f}) / \bar{f}
$$

which represents the random motion relative to the mean. The kinetic energy of random motion is $1 / 2\left(u^{\prime}\right)^{2}$. 
Combining Eqs. (2) \& (3), we have the mean kinetic energy

$\frac{1}{2} \overline{u^{\prime 2}}=\frac{1}{2 S} \int_{-\infty}^{\infty}\left(u^{\prime}\right)^{2} F(f) \mathrm{d} f=\frac{1}{S} \int_{-\infty}^{\infty} \frac{2 C^{2}}{\bar{f}^{2}}(f-\bar{f})^{2} F(f) \mathrm{d} f=\frac{1}{2}\left(\frac{C}{\bar{f}} \sigma\right)^{2}$

which is the half spectrum width in the ADCP data string. Therefore, the spectrum width from a Doppler spectrum is equal to the mean magnitude of random motion velocities of particles or backscatterers in a given water volume. If these backscatterers are mesozooplankton such as euphausiids, the square of a spectrum width provides a direct estimate to their swimming energy.

An ADCP pings with a finite pulse length. The width of a power spectrum is determined by both the pulse length of a ping and the random motion of backscatterers. The spectrum broadening due to a finite pulse length is a system constant, and can be subtracted from the ADCP spectrum width measurements. The residuals are contributed by the random motion of backscatterers.

Our surveys aimed at resolving circulation patterns and euphausiid distributions during tidal periods in fjords. To achieve this, we started with a fast ADCPsurvey to determine the presence of krill aggregations from acoustic backscattering measurements, and then conducted a transect of several MOCNESS tows inside and outside these aggregations to ensure that the acoustic targets were euphausiids. A series of studies followed the initial acoustic and MOCNESS surveys, such as CTD transects, $24 \mathrm{~h}$ ADCP transects, microstructure turbulence measurements, and euphausiid physiological measurements.

\section{RESULTS}

The absolute abundance of each species in the inner part of Ullsfjorden and Sørfjorden estimated from net tow samples is given in Table 1. The composition and sizes of euphausiid species in both fjords remained relatively unchanged over the winter (Fig. 2). Thysanoessa raschii was the only dominant species in Sørfjorden during both seasons, T. raschii, T. inermis and Meganyctiphanes norvegica were the dominant species in Ullsfjorden during spring, and $T$. inermis the only dominant species forming aggregations in Ullsfjorden during late fall (Table 1). The total abundance of euphausiids increased from the fall through winter to spring. In late fall, Calanus finmarchicus was absent from the water column, remaining in deep water or near the bottom for overwintering. In the spring, although $C$. finmarchicus numerically dominated the samples, euphausiids were the dominant backscatterers in the water column, because an average sized euphausiid produces $10^{2}$ to $10^{3}$ times higher backscattering than an average sized $C$. finmarchicus. Taking an adult $C$. finmarchicus of $2.6 \mathrm{~mm}$ in length and a target strength of approximately $-110 \mathrm{~dB}$ at $153 \mathrm{kHz}$ (Greenlaw 1977, Zhou et al. 1994), the volume backscattering of approximately $-73 \mathrm{~dB}$ produced by $C$. finmarchicus at the maximum abundance of 4243 ind. $\mathrm{m}^{-3}$ is equivalent to the volume backscattering produced by 17 euphausiids $\mathrm{m}^{-3}$ at a mean body length of $2.6 \mathrm{~mm}$. The mean abundance within euphausiid aggregations was approximately 38 and 100 ind. $\mathrm{m}^{-3}$ in Ullsfjorden and Sørfjorden, respectively. Thus, the presence of $C$. finmarchicus in spring could contribute relative errors of 50 and $20 \%$ to euphausiid estimates in Ullsfjorden and Sørfjorden, respectively. Although distinguishing euphausiids from C. finmarchicus directly from ADCP volume acoustic backscattering is impossible, we are able to distinguish euphausiid aggregations from $C$. finmarchicus on the basis of their swimming characteristics (see 'Discussion'). The abundance of Sagitta elegans was similar to that of euphausiids (Table 1). Studies of acoustic target strength of chaetognaths are very rare. Because $S$. elegans showed a very different diel vertical migration pattern from that of euphausiids in both seasons, we were able to distinguish their contribution to the acoustic volume backscattering, i.e. they produced relatively weak acoustic backscattering.

Table 1. Abundance of zooplankton species (ind. $\mathrm{m}^{-3}$ ) collected by net tow in Ullsfjorden and Sørfjorden, northern Norway

\begin{tabular}{|c|c|c|c|c|c|c|c|c|c|c|c|c|}
\hline \multirow[t]{3}{*}{ Species } & \multicolumn{6}{|c|}{ Spring } & \multicolumn{6}{|c|}{ Fall \& winter } \\
\hline & \multicolumn{3}{|c|}{ Ullsfjorden } & \multicolumn{3}{|c|}{ Sørfjorden } & \multirow{2}{*}{\multicolumn{3}{|c|}{$\begin{array}{c}\text { Ullsfjorden } \\
\text { Mean Median Max. }\end{array}$}} & \multicolumn{3}{|c|}{ Sørfjorden } \\
\hline & Mean & Median & Max. & Mean & Median & Max. & & & & Mean & Median & Max. \\
\hline Thysanoessa raschii & 5.74 & 1.98 & 38.72 & 31.07 & 3.14 & 647.96 & 0.57 & 0.04 & 5.95 & 25.60 & 9.8 & 271.07 \\
\hline Thysanoessa inermis & 7.42 & 4.40 & 22.49 & 1.11 & 0.41 & 14.62 & 3.74 & 0.30 & 48.71 & 3.53 & 1.17 & 24.32 \\
\hline Thysanoessa longicaudata & 0.16 & 0.31 & 1.06 & 0.06 & 0.16 & 0.44 & 0.19 & 0.15 & 1.47 & 0.05 & 0.11 & 0.24 \\
\hline Meganyctiphanes norvegica & 2.43 & 1.85 & 13.84 & & & & 0.08 & 0.08 & 0.73 & & & \\
\hline Calanus finmarchicus & 481.87 & 173.204 & 4243.26 & 498.10 & 242.39 & 2463.21 & & & & & & \\
\hline Sagitta elegans & 2.49 & 0.51 & 20.59 & 34.09 & 9.51 & 301.31 & 0.00 & 0.00 & 0.00 & 31.04 & 38.00 & 216.38 \\
\hline
\end{tabular}



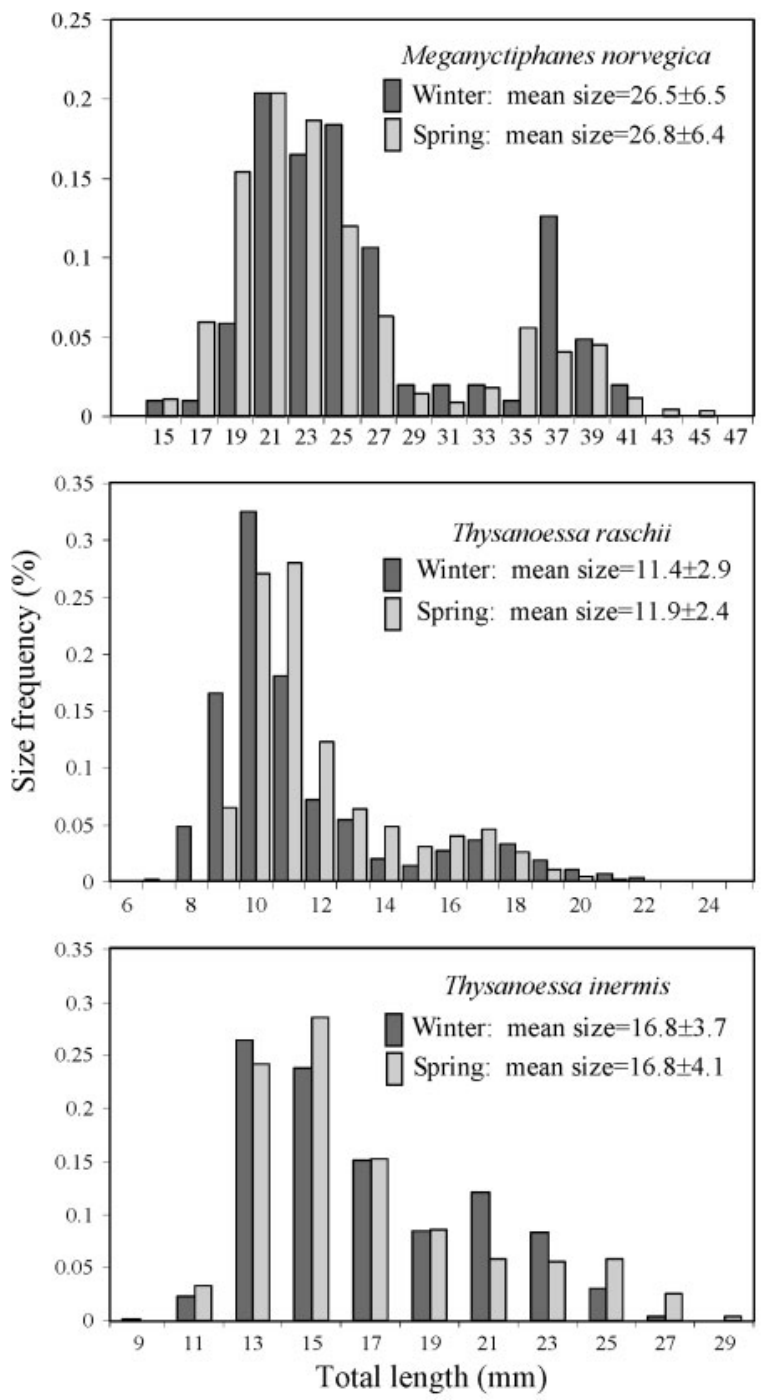

Fig. 2. Meganyctiphanes norvegica, Thysanoessa raschii and $T$. inermis. Size frequencies during fall-winter and spring survey periods in both fjords

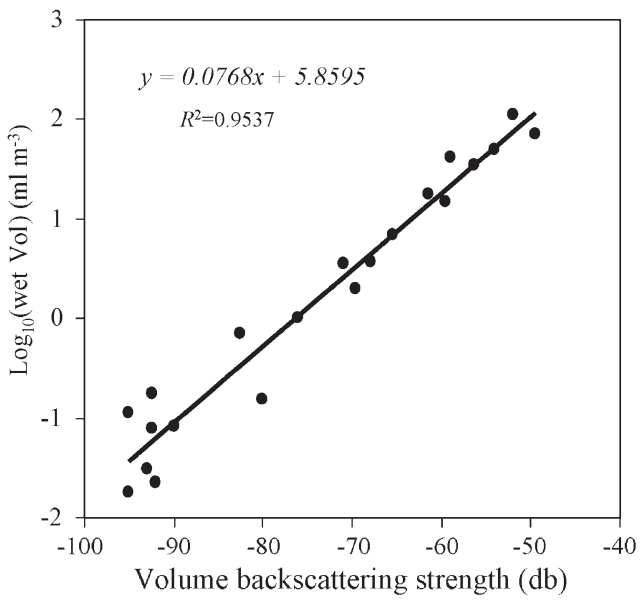

Fig. 3. ADCP volume backscattering strength measurements and wet volumes of euphausiids in MOCNESS tow samples

Echo intensity measurements were extracted from ADCP raw data based on the time, location and depth intervals of a net tow, and converted to absolute volume backscattering (VTS) using the standard sonar equation (RD Instruments 1990). A straight linear correlation between wet weights of euphausiids from net tow samples and corresponding VTS estimates from ADCP data on the log chart is reflected by an $\mathrm{R}^{2}$ of approximately 0.95 (Fig. 3). Thus, we were able to measure euphausiid swarms from the backscattering and their movements from first and second moments of a Doppler spectrum at the same time and same location during our study (Fig. 4).

The transects of temperature, salinity and fluorescence concentration along the principal axes of Ullsfjorden and Sørfjorden in the fall cruise are shown in Fig. 5, and transects of temperature and salinity in the spring cruise in Fig. 6. Measurements along one of these transects took approximately $8 \mathrm{~h}$. If we take a

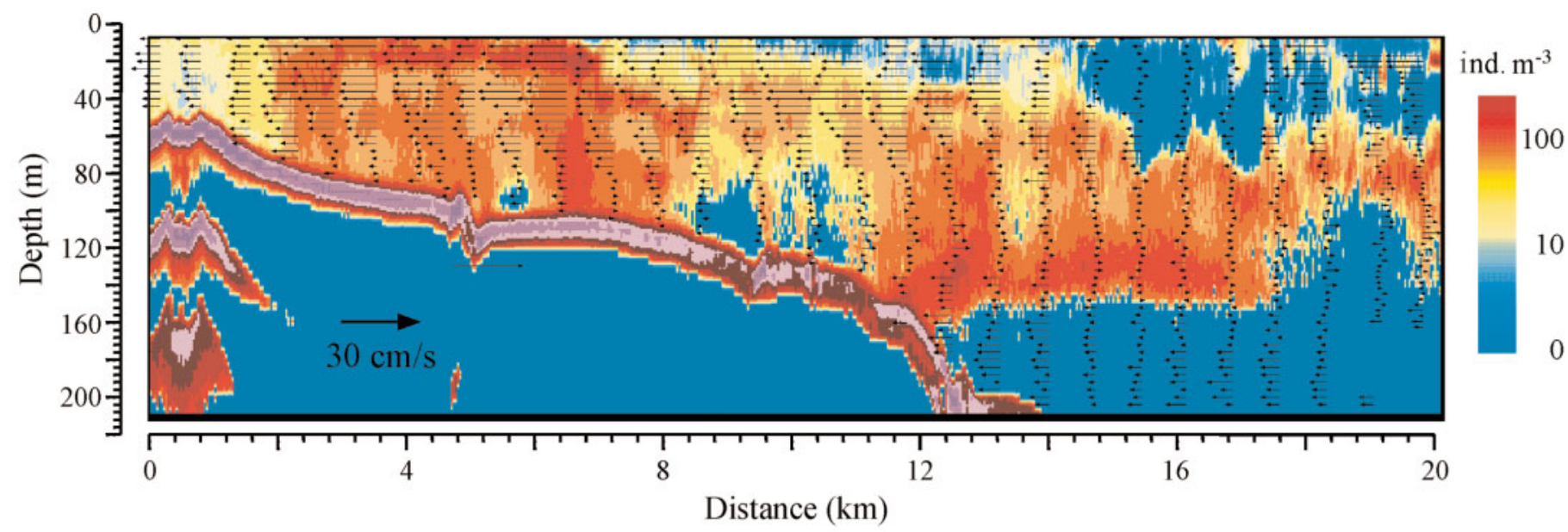

Fig. 4. ADCP transect along the principal axis at Ullsfjorden on April 14, 1996, from Stns 20 to 30. Arrows represent horizontal currents along the principal axis; color key: abundance of euphausiids (ind. $\mathrm{m}^{-3}$ ), assuming a mean length of $1.2 \mathrm{~cm}$ 
mean tidal current of approximately $15 \mathrm{~cm} \mathrm{~s}^{-1}$ in Ullsfjorden and $5 \mathrm{~cm} \mathrm{~s}^{-1}$ in Sørfjorden during flood or ebb, the tidal current excursions are approximately 3 and $1 \mathrm{~km}$, respectively. Thus, temperature and salinity fields in Figs. 5 \& 6 are not synoptic, and are biased in association with excursions of water parcels induced by tidal currents and the time lags between stations.

The heat budgets in these 2 fjords can be determined from the temperature structures and their seasonal changes (Figs. 5, $6 \&$ 7). During the survey period in late fall, waters in both Ullsfjorden and Sørfjorden were warmer than in late winter and early spring. Local bottom water formation is reflected by the coolest and saltiest bottom water in the inner basin of Sørfjorden. Through the winter, heat loss led to much cooler waters in these 2 fjords, except for the deep water in Ullsfjorden, which was unchanged, and comprised modified water originating from the Norwegian shelf, characterized by temperature $>5.5^{\circ} \mathrm{C}$ and salinity > 34.5 (Ljøen 1962).

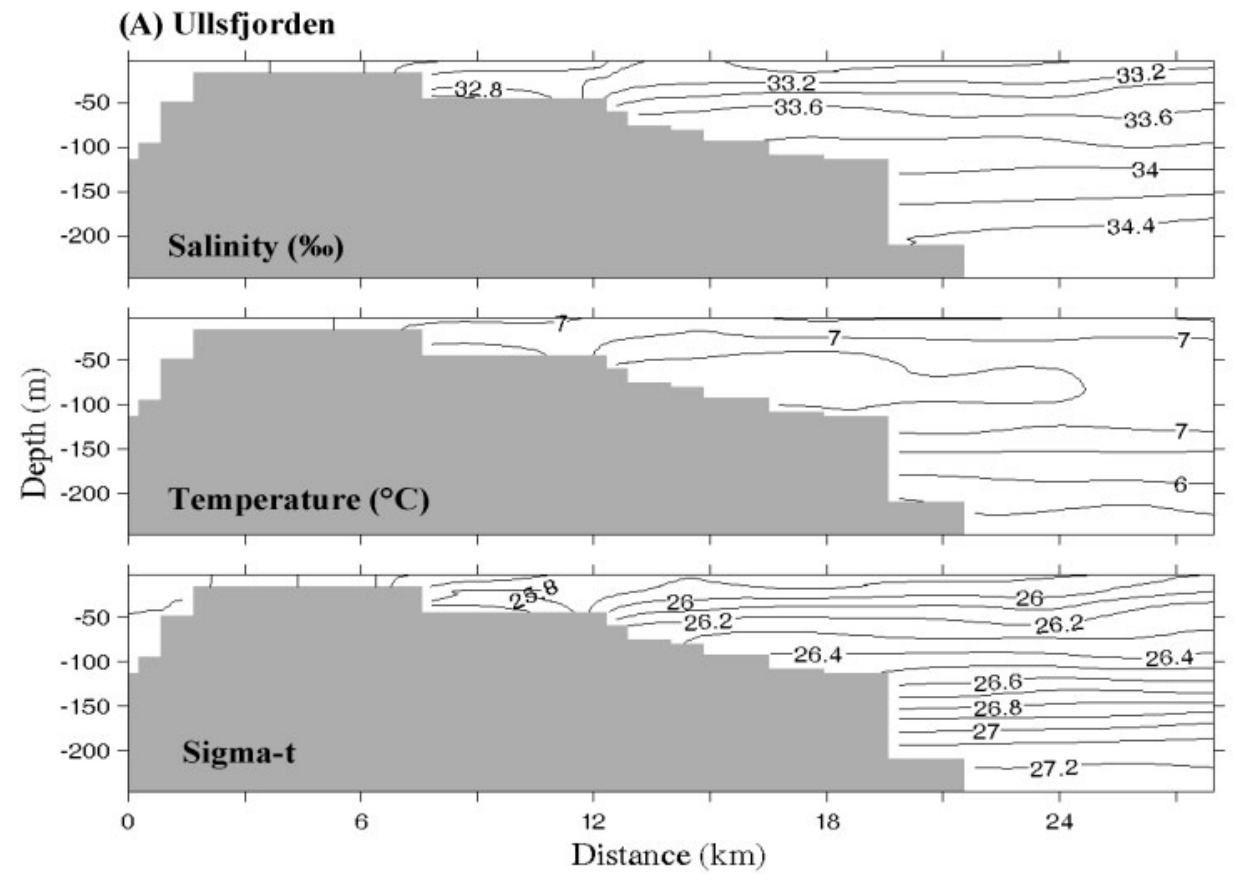

(B) Sørfjorden

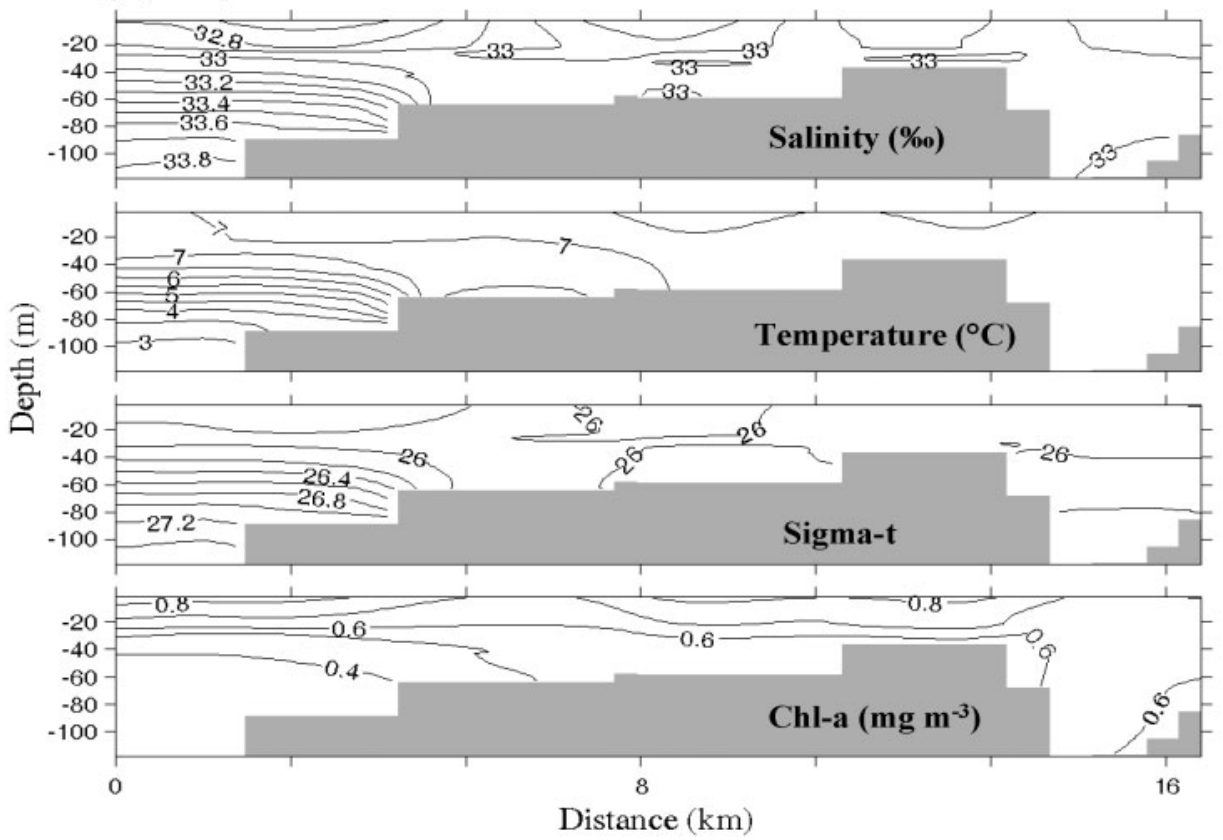

Fig. 5. (A) Temperature, salinity and $\sigma_{t}$ transects along principal axes at Ullsfjorden on October 30, 1995, from Stns 19 to 30 ; (B) temperature, salinity, $\sigma_{t}$ and fluorescence transects along principal axes at Sørfjorden on October 29, 1995, from Stns 1 to 19 
Time series of ADCP measurements of currents and zooplankton biomass were taken to determine the impact of combined current advection and vertical migration of zooplankton on their transport and retention during both the fall and spring cruises. To determine the timing of upward and downward migration of euphausiids and their activities in the water column, we used the theoretical photosynthetically available radiation (PAR) without cloud correction $\left(\mathrm{W} \mathrm{m}^{-2}\right)$ for the light field as the cue triggering the onset of migra- tion, fluorescence measurements (voltage) as the food field for euphausiids, and ADCP VTS estimates (ind. $\mathrm{m}^{-3}$ ) for monitoring euphausiid migration at Stns 7 and 8 in Sørfjorden (Figs. 8 \& 9). For the ADCP VTS unit $(\mathrm{dB})$ conversion to ind. $\mathrm{m}^{-3}$ we assumed a target strength of $-86 \mathrm{~dB}$ at $153 \mathrm{kHz}$ for a $1.2 \mathrm{~cm}$ euphausiid. Note that both theoretical PAR values and fluorometer voltages are used only for the purpose of illustrating temporal and spatial variations. The results clearly indicate that euphausiids maintained their diel vertical

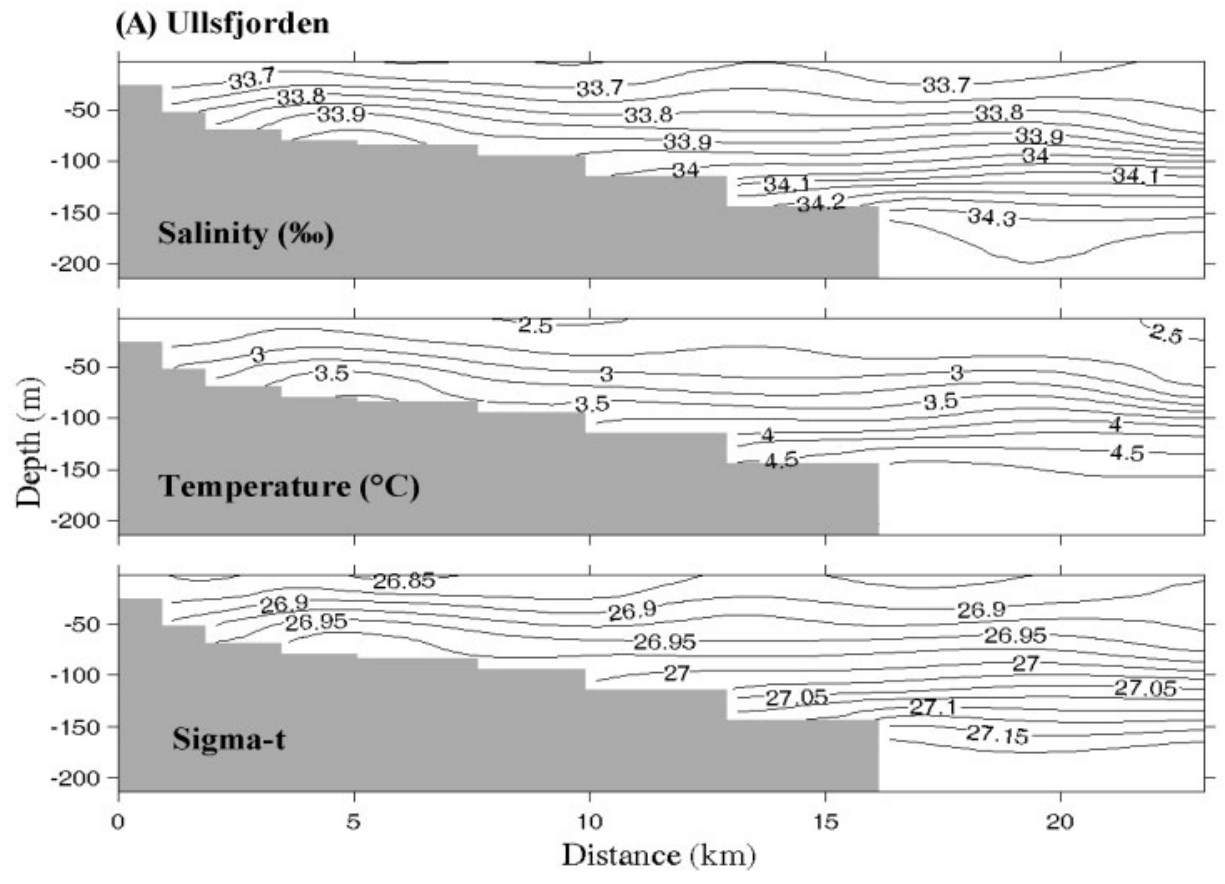

Fig. 6. Temperature, salinity and $\sigma_{t}$ transects along principal axes at (A) Ullsfjorden on April 14, 1996, from Stns 20 to 30, and (B) Sørfjorden on April 10, 1996, from Stns 1 to 19

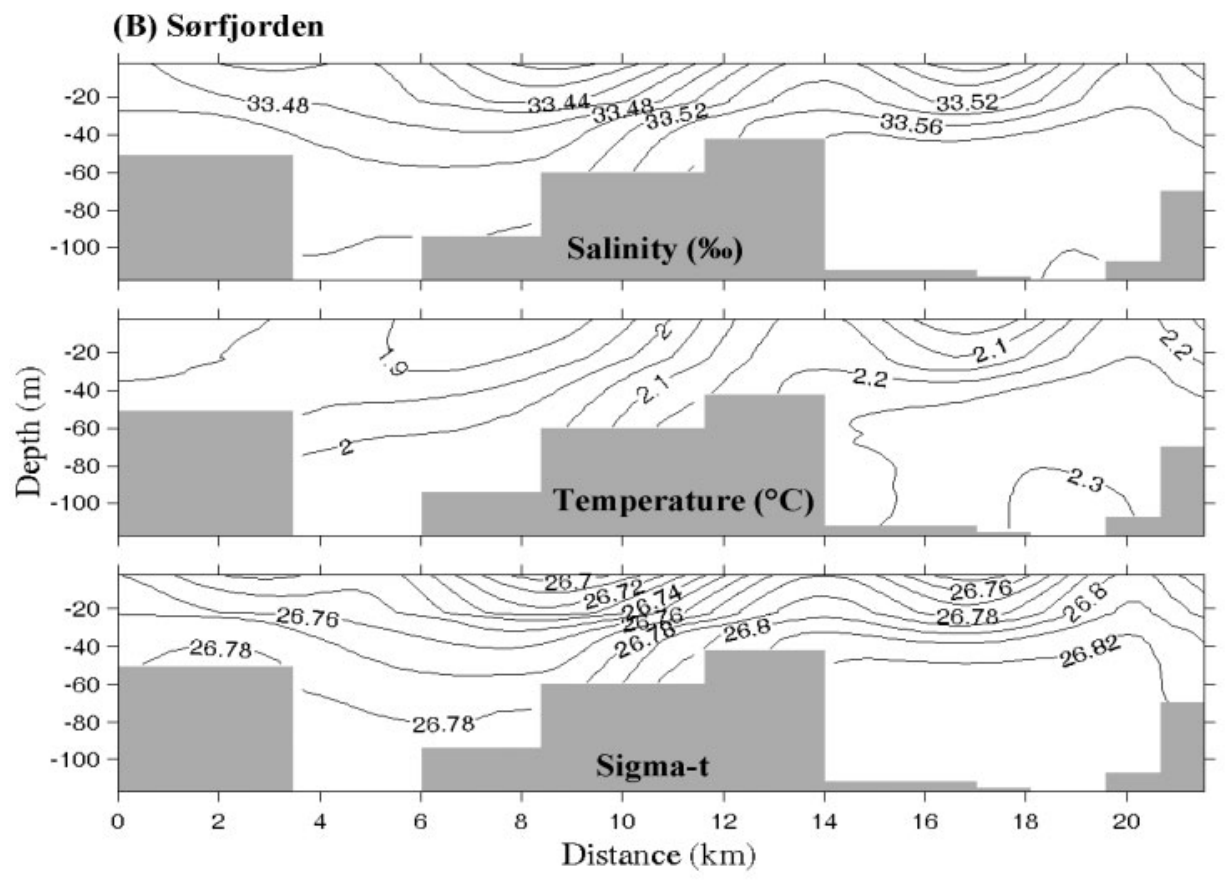




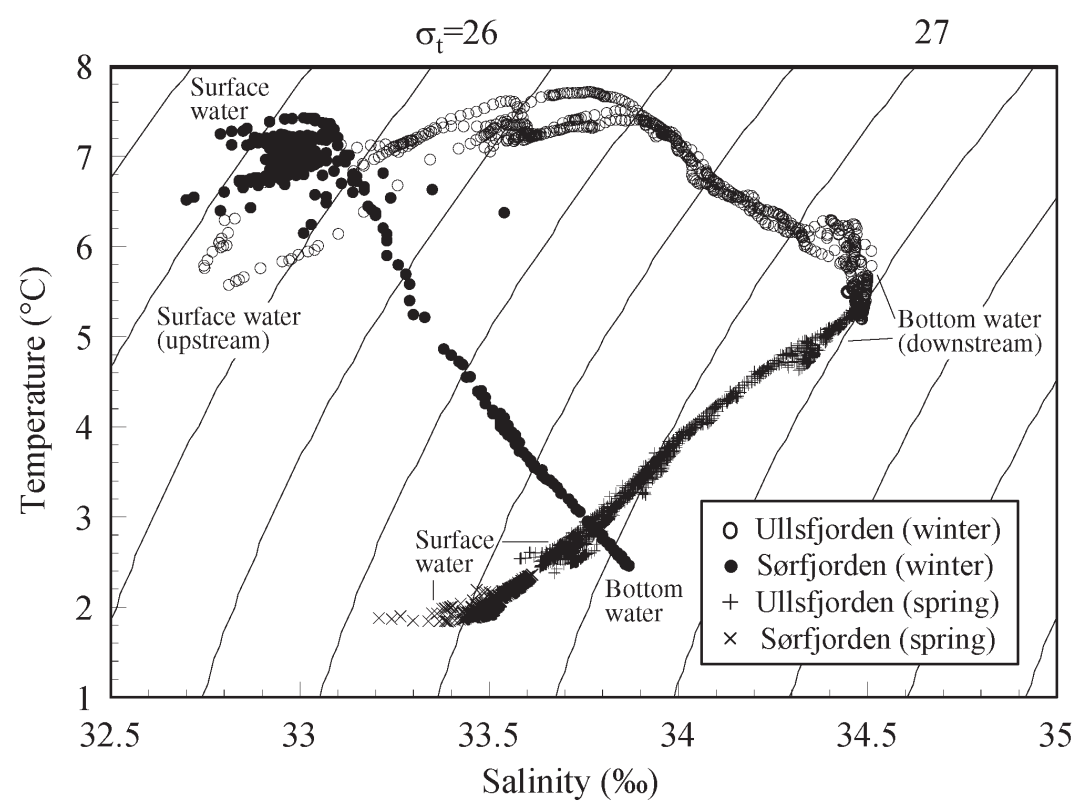

Fig. 7. Temperature and salinity at all CTD stations in Ullsfjorden and Sørfjorden migration pattern in both the spring and fall. They quickly moved down to depths near the bottom at dawn. Photosynthetic activity led to an increase in fluorescence concentration in the upper water column during the day. At sunset, the euphausiids ascended into the upper water column to graze, leading to a decrease in fluorescence concentration at night.

Current measurements included both tidal and buoyancy driven currents. Barotropic current (including periodical barotropic tidal currents) data can be extracted by subtracting the vertically averaged mean current. The differential horizontal currents shown in Figs. 10 \& 11 are the component along the principal axes in the inner basin of Sørfjorden on October 27 and in Ullsfjorden on November 15 and 16, 1995. Because the
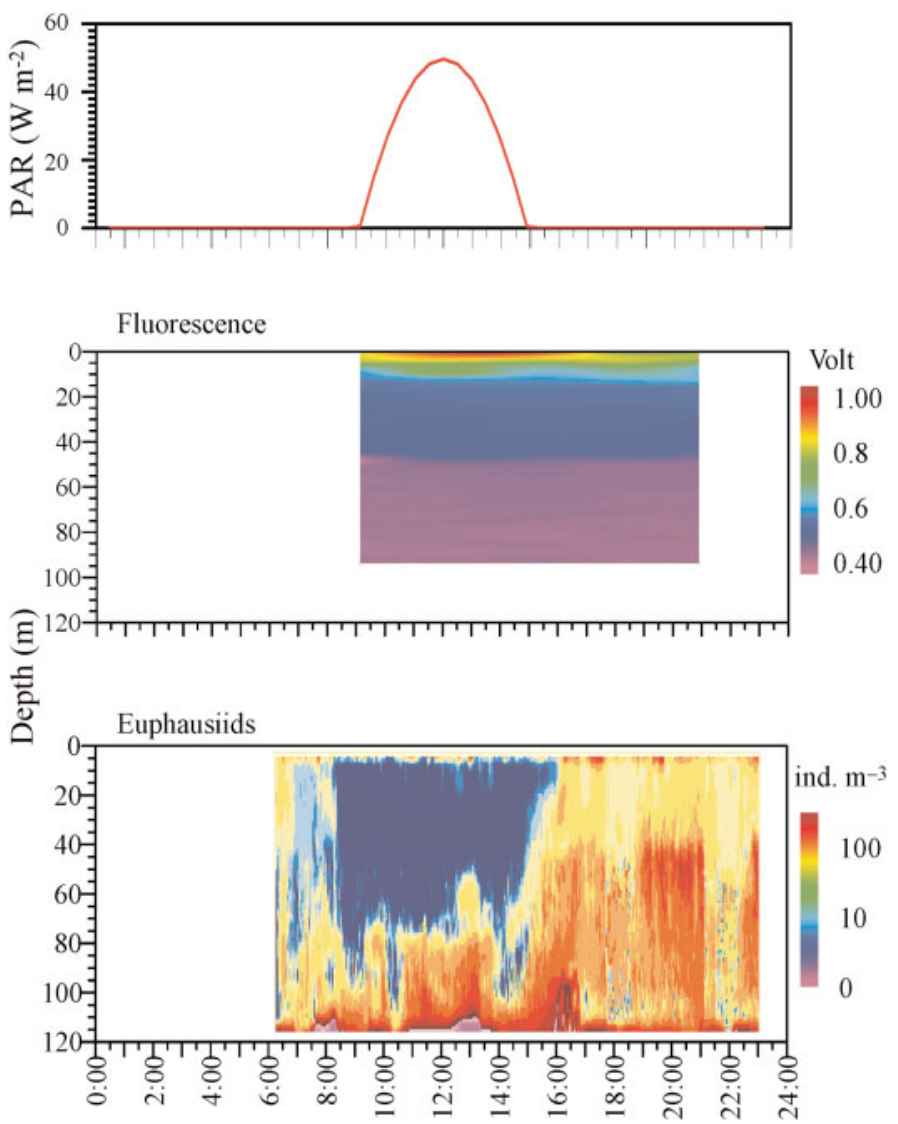

Time $(\mathrm{h})$

Fig. 8. Time series of theoretical photosynthetically available radiation, fluorescence concentration, and euphausiid abundance estimated from ADCP volume backscattering estimates (ind. $\mathrm{m}^{-3}$ ) at $\mathrm{Stn} 8$ in Sørfjorden on November 1, 1995
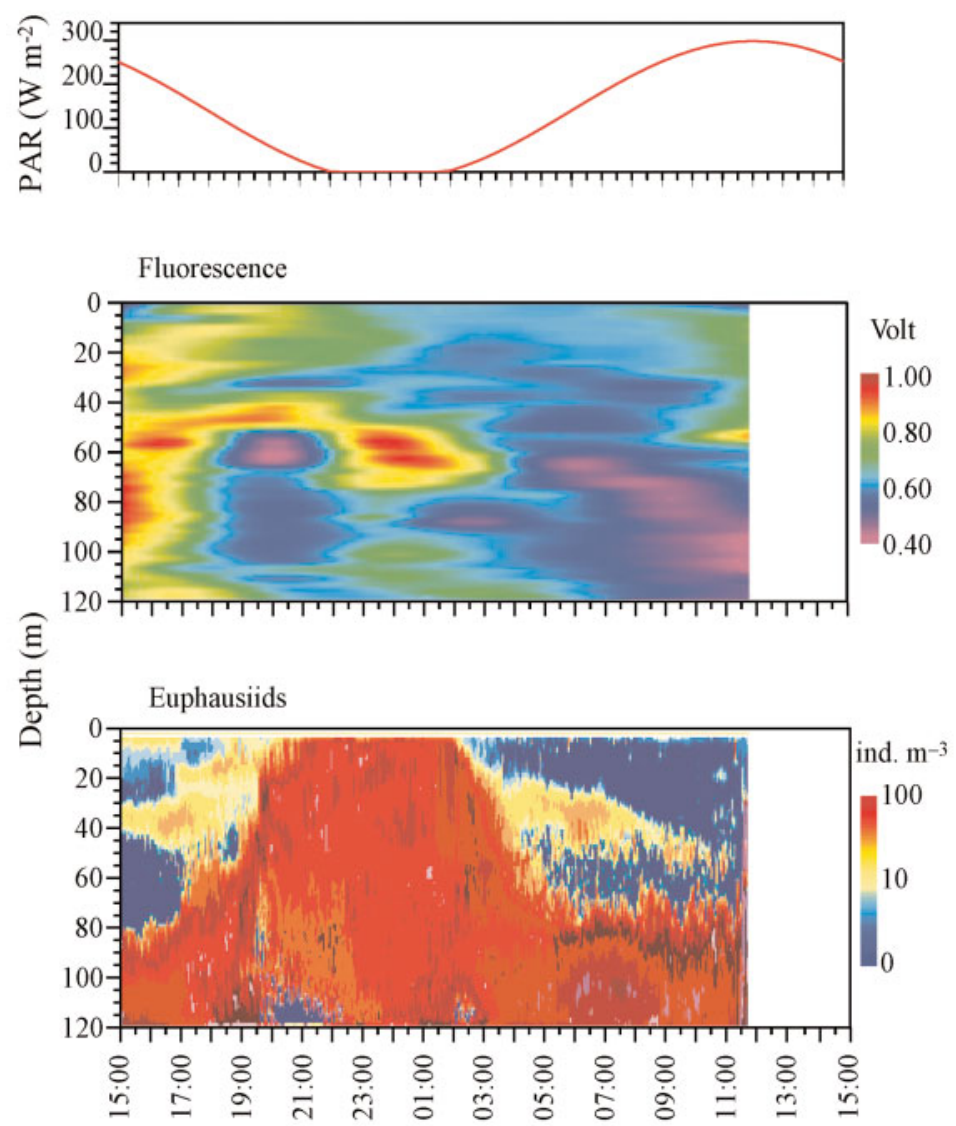

Time (h)

Fig. 9. Time series of theoretical photosynthetically available radiation, fluorescence concentration, and euphausiid abundance estimated from ADCP volume backscattering estimates (ind. $\mathrm{m}^{-3}$ ) at Stn 7 in Sørfjorden on April 12 and 13, 1996 


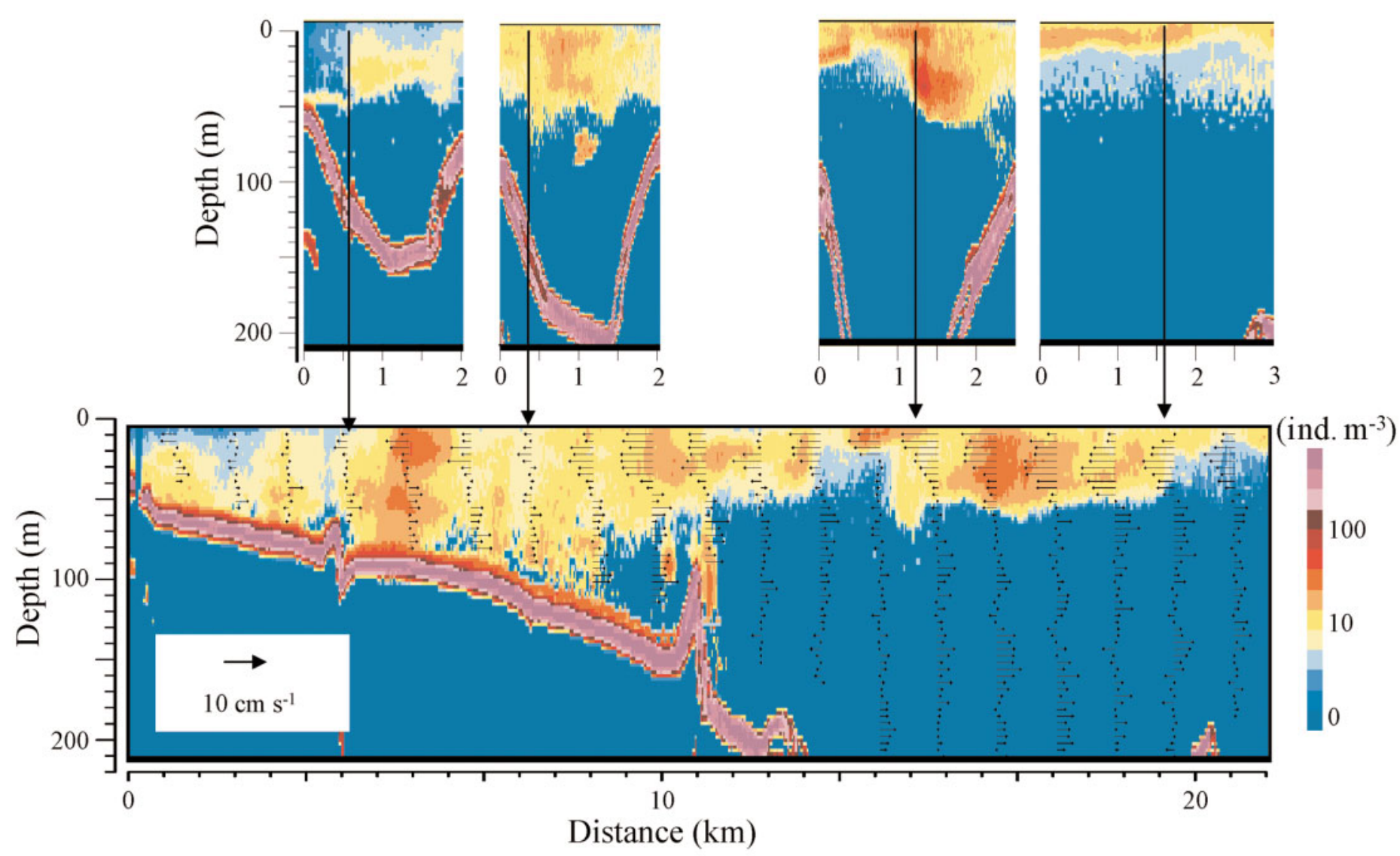

Fig. 10. ADCP transect along the principal axis at Ullsfjorden and cross-sections on November 15 and 16, 1995 , from Stns 20 to 30. Black lines: locations of transect in cross-sections and of cross-sections in transect. Arrows along transect: horizontal differential currents along principal axis; color key: abundance of euphausiids (ind. $\mathrm{m}^{-3}$ ), assuming mean length of $1.2 \mathrm{~cm}$

directions of the currents differed between the upper and lower water columns, the direction of advective transport of euphausiids also differed, depending on the depth of an aggregation, which again varied dielly. To reveal the effect of this advection on euphausiid aggregations, VTS color images of euphausiid estimates were superimposed on the current vectors (Figs. 10 \& 11). To determine the euphausiid distribution in a cross fjord direction, several cross sections were made (Figs. 10 \& 11). Because there were no euphausiid aggregations in the outer basin of Sørfjorden during our 2 survey periods, only results for the inner basin of Sørfjorden are shown. The results indicate that the euphausiids remained in the upper water column during the long nights of this period.

The movements of euphausiid aggregations within a tidal period were studied during the spring cruise (Figs. 12 \& 13). Because of the time limits of the survey and the size of euphausiid patches, only along-fjord transects were conducted. To ensure that the spatial distribution of euphausiids was not biased by temporal variation of tidal currents, each transect along a fjord was made within a period of $1.5 \mathrm{~h}$. Typically, a total of 8 transects was covered at equal time intervals during a period of $24 \mathrm{~h}$. The velocity vectors, comprising the horizontal component in the fjord principal axis and the vertical component, are shown in Figs. 12 \& 13. The vertical, near surface velocity was almost 10 to $15 \mathrm{~cm} \mathrm{~s}^{-1}$. This is not attributable to vertical motion of the vessel, because the sea in the fjords was very calm, nor to any known physical processes. Because the dominant backscatterers were euphausiids (verified by net tow samples: Figs. 14 \& 15, Table 1), the vertical velocity components of 10 to $15 \mathrm{~cm} \mathrm{~s}^{-1}$ may have been due euphausiid aggregations (Kils 1979, 1983).

The velocity measurements and volume backscattering estimates for the euphausiids were made at the same times and locations. They demonstrate temporal variation in transport of euphausiids as a function of temporal variation in tidal currents. In the spring, both fjords displayed an estuarine circulation, with a net outflow in the upper water column and a net inflow in the lower water column (Figs. 12 \& 13). Euphausiids remained deep in the water column during the long daylight hours and fed in the upper layer during the short hours of night. 


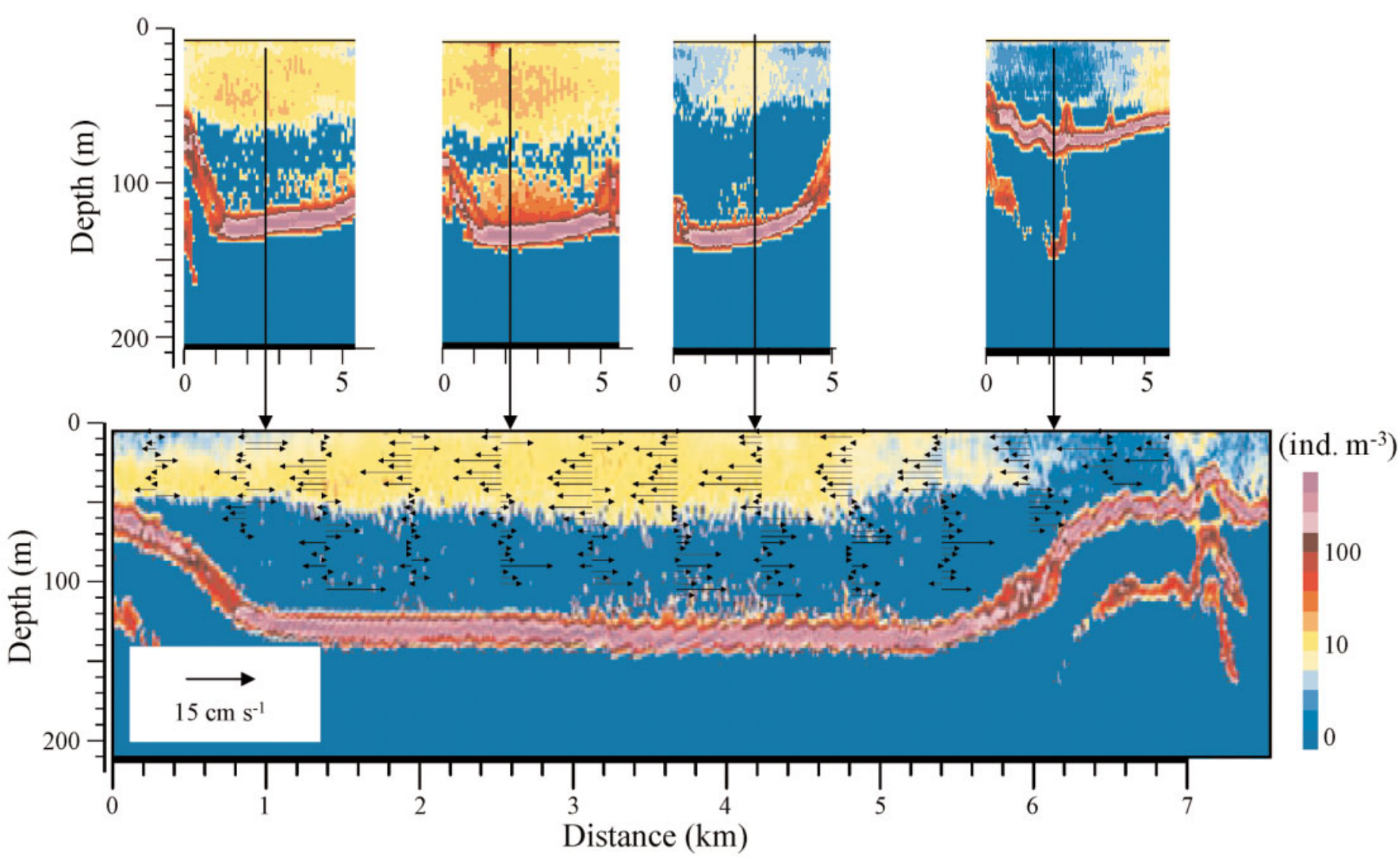

Fig. 11. ADCP transect along the principal axis at Sørfjorden and cross-sections on October 27, 1995, from Stns 4 to 8 . Further details as for Fig. 10

The aggregational behavior of euphausiids is also evident in Figs. 10 to 13. The variables which may potentially be used to describe this quantitatively, such as mean swimming speed, random motion velocities and auto-coherence, were further explored by ADCP velocity measurements. The errors of both velocity and spectrum width measurements of an ADCP are inversely proportional to the pulse length transmitted. To increase the accuracy of these measurements in distinguishing velocity differences with and without euphausiids, we increased the pulse length to $8 \mathrm{~m}$, leading to an accuracy of $1 \mathrm{~cm} \mathrm{~s}^{-1}$, with a $5 \mathrm{~min}$ average. While the volume backscattering provided estimates of euphausiid abundance distributions, the spectrum width measurements reflected the random movements of euphausiids inside and outside a swarm (Fig. 16).

\section{DISCUSSION}

\section{Seasonal changes in fjord thermal structure and circulation}

Surface cooling in late fall was obvious from the cooler surface water, compared to the warmer mid-depth wa- ter, in both Ullsfjorden and Sørfjorden (Fig. 5). The warm mid-depth waters in both fjords are typically interpreted to comprise the water formed through surface heating in spring, summer and early fall. During the survey period in late fall, the bottom water in Sørfjorden was cooler and saltier upstream than downstream, and its horizontal density gradient was stronger, a further indication of surface cooling. Such a density gradient is a unique feature of high-latitude fjords, which differ from mid-latitude fjords, in which salinity and density are typically lower upstream than downstream. Local bottom water formation is confirmed by the temperature and salinity (T-S) diagram (Fig. 7), which shows the coolest and saltiest bottom water in the inner basin of Sørfjorden located far distant from the bottom water downstream or the water in Ullsfjorden. Ice formation at the surface of both fjords was observed during our fall cruise, although this never remained long. A mixture of brine from the ice and surrounding water formed cool and salty water that sank to the bottom. This process occurs earlier upstream in a fjord, because the upstream section has usually less heating capacity, and less heat flux from the ocean. We refer to this as a reversed horizontal density gradient compared to that in mid-latitudes. A similar reversed density gradient was found in Ullsfjorden. 

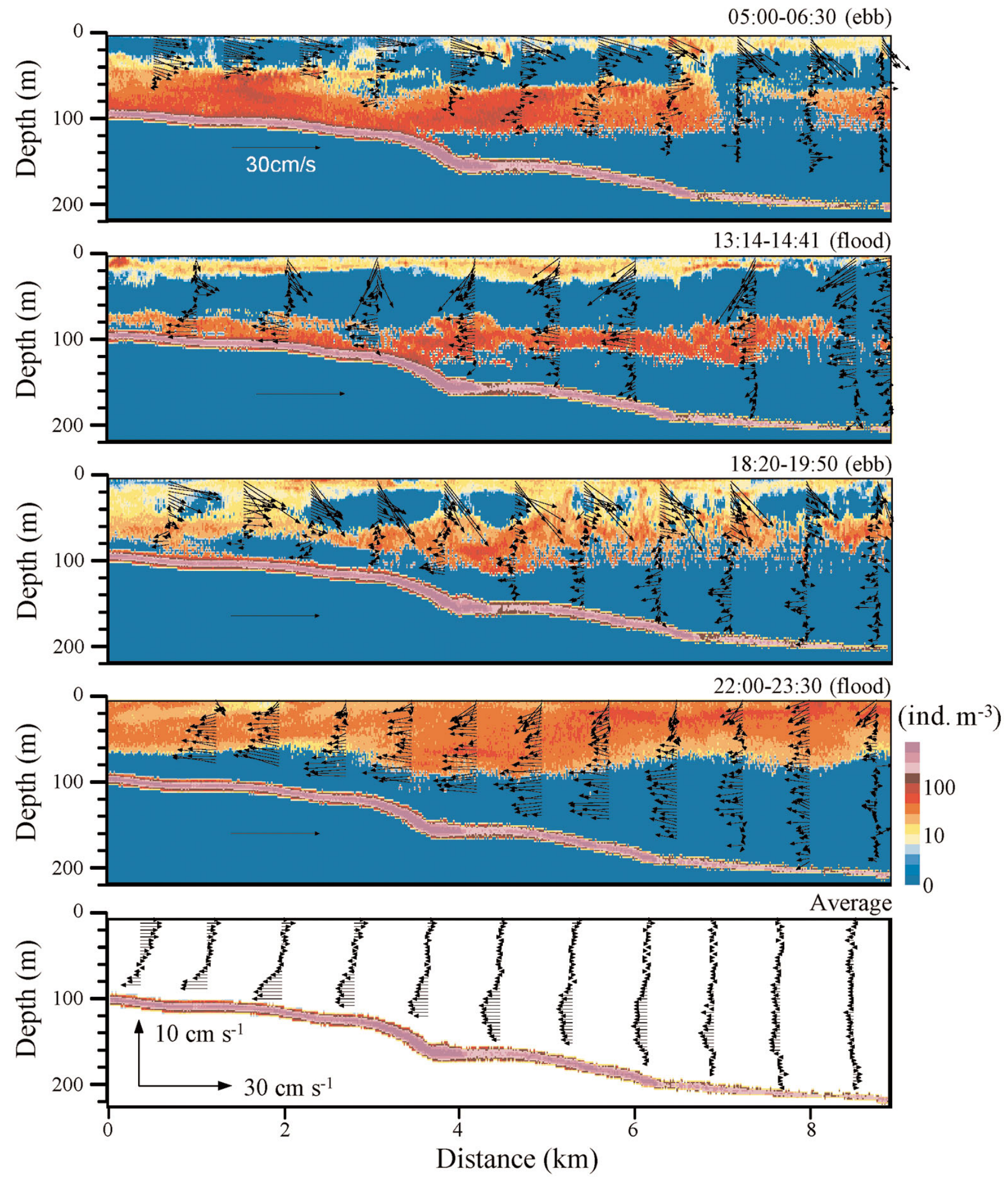

Fig. 12. ADCP transect along the principal axis at Ullsfjorden on April 17, 1996, from Stns 23 to 27. Arrows represent horizontal currents along principal axis; color key: abundance of euphausiids (ind. $\mathrm{m}^{-3}$ ), assuming mean length of $1.2 \mathrm{~cm}$. Bottom graph shows residual currents (average for 12 transects over $24 \mathrm{~h}$ period) 


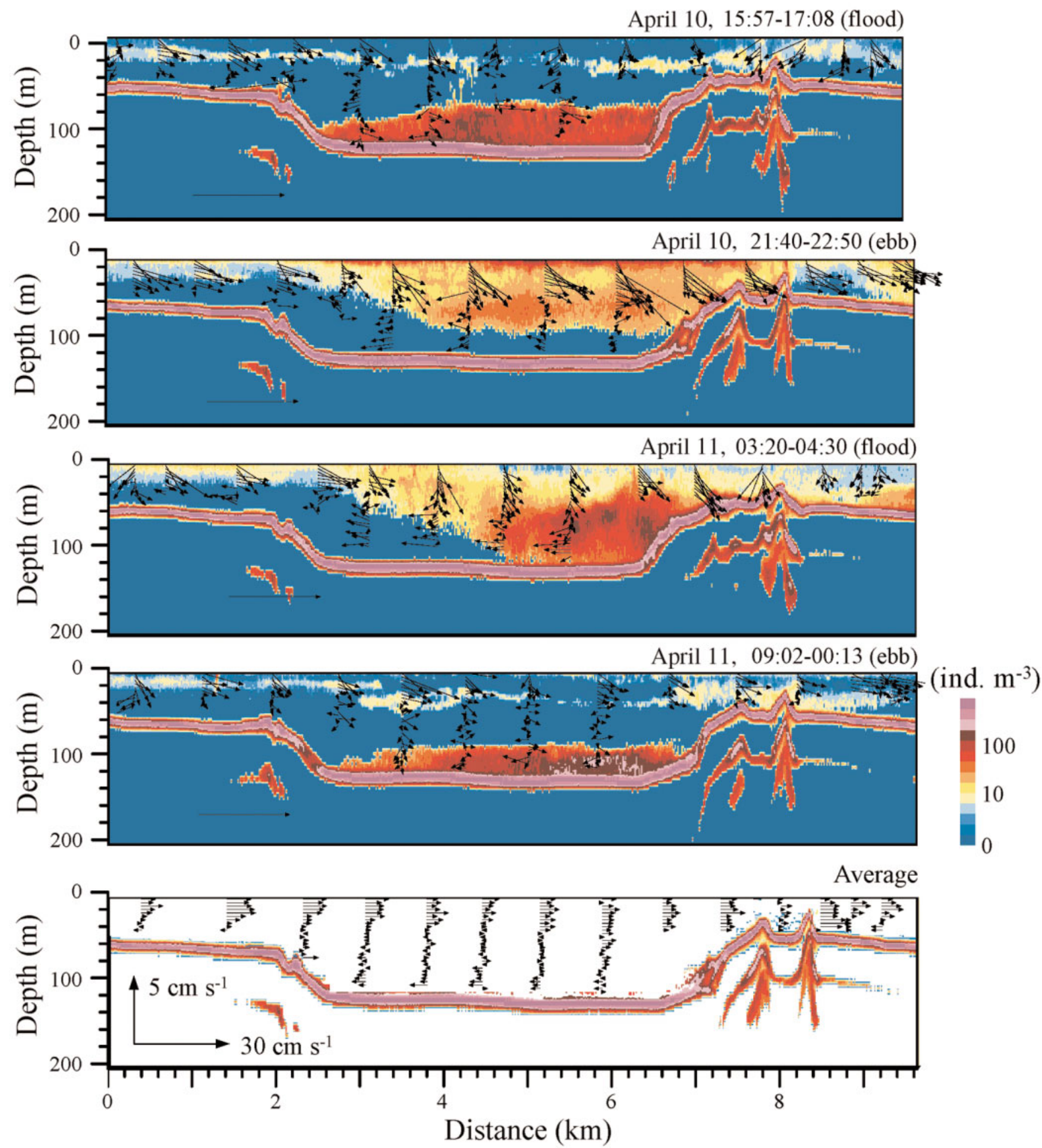

Fig. 13. ADCP transect along the principal axis at Sørfjorden on April 10 and 11, 1996, from Stns 3 to 8. Further details as for Fig. 12

The reversed density gradient in the fall and winter produces a reversed estuarine circulation, with a bottom outflow and a surface inflow. This is confirmed by the ADCP current measurements (Figs. 10 \& 11). The circulation was driven by local cooling on a basin scale, since mixing between Ullsfjorden and Sørfjorden waters is not apparent from the T-S data. The coolest and saltiest bottom water in the inner basin of Sørfjorden did not extend to the outer basin and Ullsfjorden. 

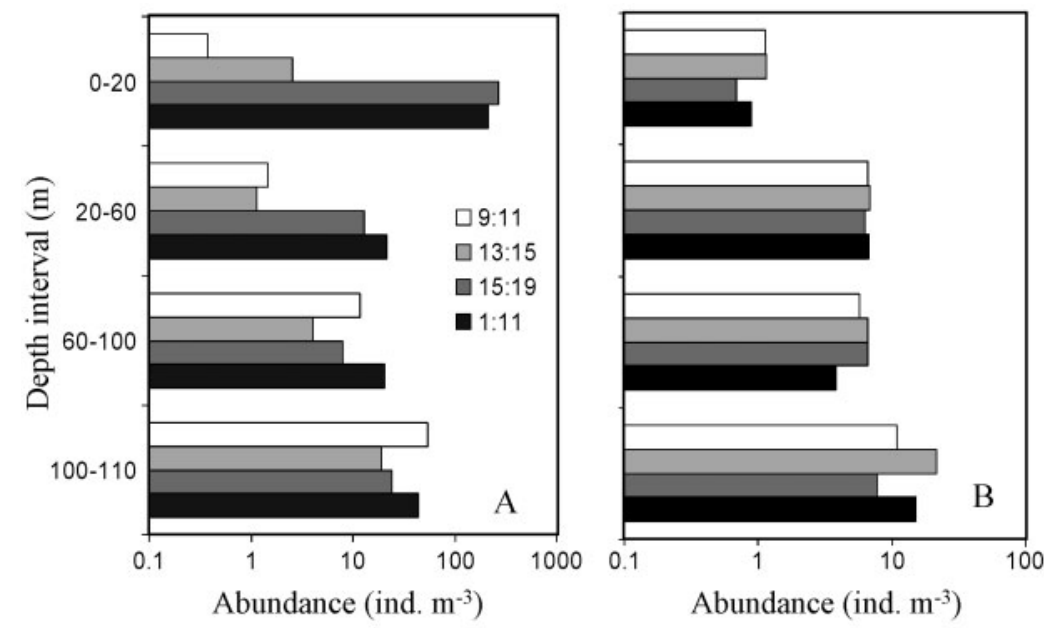

Fig. 14. (A) Thysanoessa raschii; (B) Sagitta elegans. Abundance as a function of depth intervals from 2 nighttime MOCNESS tows and 2 daytime tows at Stn 6 in Sørfjorden during fall-winter cruise. Key: time of day net tow began
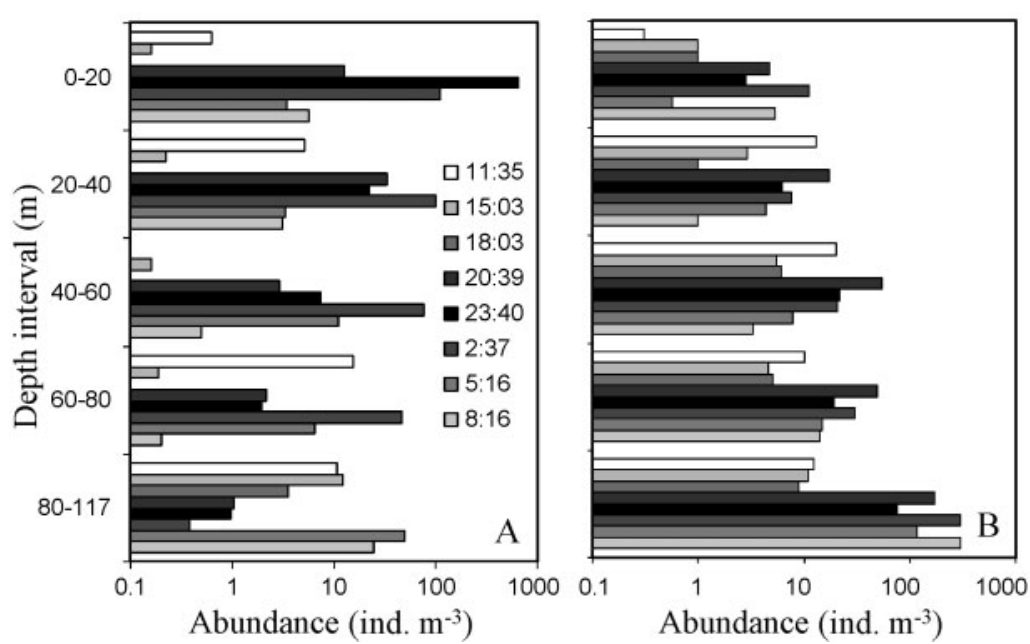

Fig. 15. (A) Thysanoessa raschii; (B) Sagitta elegans. Abundance as a function of depth intervals from 8 MOCNESS tows within 24 h at Stn 6 in Sørfjorden during spring cruise. Key: time of day net tow began

The heat loss during fall and winter is examined by comparing the thermal structure in late fall to that in spring (Figs. $6 \&$ 7). In the spring, the warm water layers found at mid-depth during the fall cruise were absent, having completely disappeared over the winter. The coolest water was at the surface. Although the smaller heat capacity in Sørfjorden made the water there cooler than in Ullsfjorden, the higher salinity of Ullsfjorden water made its density higher than that of Sørfjorden water. The T-S diagram (Fig. 7) in spring consisted of an almost straight line, implying mixing of the waters of these 2 fjords. The intrusion of denser bottom water into Sørfjorden from Ullsfjorden is illustrated in Fig. 6B.
The current comprises 2 components, buoyancy-driven and tidal currents. The periodic tidal current component can be removed by averaging current measurements over a tidal period. The residual current from averaging 8 transects of current measurements during the spring cruise represents the buoyancy-driven current (Figs. 12 \& 13), a typical estuarine circulation pattern, with a surface outflow of low density water from upstream and an intrusive bottom current of saltier and denser oceanic water (Dyer 1997). Superimposing the buoyancy current onto the ebb tidal current should result in a strong ebbing surface flow, since both buoyancy-driven and tidal currents would be in the same direction; and in a weak bottom current due to a counterbalance between the ebb tidal current and inflow of the bottom, buoyancy-driven current. During flood tides, we would expect a stronger intrusive bottom current, since both the buoyancydriven and flood tide currents would be in the same direction; and a weaker surface current due to the counter effects of freshwater runoff and tidal current.

\section{Migration and aggregation behavior of euphausiids}

The ADCP volume backscattering measurements clearly indicate the diel vertical migration of backscattering layers similar to those found in Balsfjorden (Hopkins et al. 1978, 1984). In the fall and winter, euphausiids were the absolute dominant backscatterers in the water column because of the absence of Calanus finmarchicus. In the spring, C. finmarchicus can make up to 20 and $50 \%$ of the volume backscattering in Sørfjorden and Ullsfjorden, respectively. However, the vertical velocity measurements in these ADCP volume backscattering layers were as much as $15 \mathrm{~cm} \mathrm{~s}^{-1}$, a velocity that can only be attributable to euphausiids. These velocity measurements indicate that euphausiids were the dominant backscatterers in these layers, which consisted of Thysanoessa raschii and T. inermis.

The diel vertical migration pattern of Thysanoessa raschii and $T$. inermis was further verified from daytime and nighttime MOCNESS tow samples. Although the light level was very low during our fall survey, euphausiids still maintained their diel vertical migration pattern (Fig. 14A). Because the night was very long in the fall and winter, euphausiids remained in the water column for most of the $24 \mathrm{~h}$ diurnal period (Fig. 8). At 

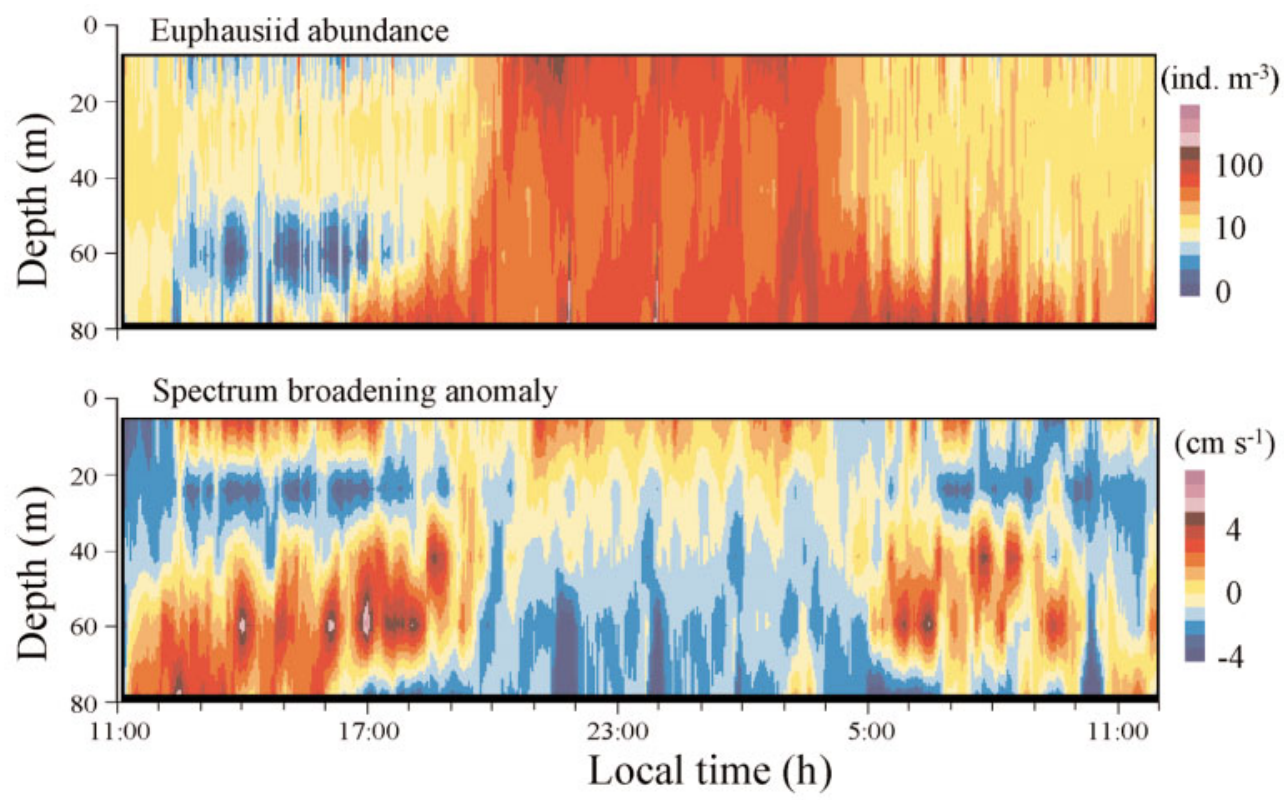

Fig. 16. Time series for euphausiid abundance estimated from ADCP volume backscattering estimates (ind. $\mathrm{m}^{-3}$ ) and random velocity anomaly $\left(\mathrm{cm} \mathrm{s}^{-1}\right)$ of organisms at Stn 6 in Sørfjorden on April 11 and 12, 1996

dawn, they quickly moved down to near bottom depths, even though the light in the upper water column was very dim. The absence of grazers and low availability of light resulted in photosynthetic activity, as indicated by increased fluorescence concentrations in the upper water layers. At sunset, the euphausiids ascended into the upper water column to graze those phytoplankton produced during the day (Fig. 8).

The migration response of euphausiids to light in the spring resembled that in the fall and winter (Fig. 15A). Because the day was much longer than the night in spring, euphausiid aggregations remained at depth for most of the daylight hours (Fig. 9). Fluorescence concentrations increased during the day, and decreased markedly when euphausiids moved to the upper water column for feeding after sunset. In both late fall and early spring, euphausiids initially moved to the surface, forming dense aggregations, and then dispersed throughout the water column. The reason for this behavior is not known, but we can speculate that they were looking for food after the surface phytoplankton had been depleted.

The red areas in Figs. 12 \& 13 indicate swarms and aggregations of Thysanoessa raschii. The yellow layers $\left(\sim 10\right.$ ind $\left.\mathrm{m}^{-3}\right)$ at the surface and shallow depths were especially visible during the day, when $T$. raschii stayed at depth. Net samples from a targeted MOCNESS tow in Ullsfjorden indicated that these layers consisted of Meganyctiphanes norvegica which did not migrate to deep water, but remained within the top $50 \mathrm{~m}$ of water column during the day. The behavior of $M$. norvegica at night was difficult to follow, since their signals were mixed with those of the dominant species, T. raschii. From the yellow layer observed during the day in
Fig. 9 and net tow samples at night, we confidently conclude that $M$. norvegica did migrate to the surface at night. Because they are strong swimmers with an average size of $2.6 \mathrm{~cm}$, and form small aggregations, standard MOCNESS depths will not efficiently sample these highly mobile euphausiids, and will often miss patchy aggregations. Only with targeted tows were we able to confirm that $M$. norvegica aggregations occur only in Ullsfjorden.

The mean abundance of Sagitta elegans in these 2 fjords resembled that of euphausiids. We investigated whether chaetognaths could contaminate the acoustic measurements of euphausiids through behavioral differences. The net tow samples indicated that Thysanoessa raschii displayed a strong diel migration behavior in both seasons, but that $S$. elegans did not (Figs. 14 $\& 15)$. We compared the acoustic measurements and net tow samples (Figs. 10 \& 13-15), whereby strong VTS was taken to indicate the presence of euphausiids, and weak VTS their absence; chaetognaths were always abundant. Strong VTS patterns paralleled the migrating euphausiid aggregations in both fjords during our survey periods, indicating that chaetognaths produce a much weaker echo than euphausiids.

The migration depth of Thysanoessa raschii was either to the bottom or to a depth of approximately 100 to $120 \mathrm{~m}$ in both the fall and spring cruises (Figs. 8 \& 9), although the maximum solar irradiance in the fall survey was approximately $50 \mathrm{~W} \mathrm{~m}^{-2}$, much lower than the $300 \mathrm{~W} \mathrm{~m}^{-2}$ in spring. Why did not the migration depth of $T$. raschii change when the sea surface irradiance changed by a factor of 6 ? Visible light decreases as a function of depth, i.e. $I=I_{0} \mathrm{e}^{-\alpha z}$, where $I$ is light intensity, $I_{0}$ is sea surface irradiance, $\alpha$ is the vertical 
extinction coefficient and $z$ is depth (Kirk 1983). We assume that euphausiids moved to depth at the same light level in both fall and spring. Taking the maximum irradiance of $300 \mathrm{~W} \mathrm{~m}^{-2}$ at the surface and an approximate value of $0.2 \mathrm{~m}^{-1}$ for the extinction coefficient of seawater in fjords (Kirk 1983), the light level at a depth of $120 \mathrm{~m}$ in the spring would be approximately $1.1 \times$ $10^{-8} \mathrm{~W} \mathrm{~m}^{-2}$. In late fall, taking a maximum surface irradiance of $50 \mathrm{~W} \mathrm{~m}^{-2}$, the light would be reduced to $1.1 \times$ $10^{-8} \mathrm{~W} \mathrm{~m}^{-2}$ at a depth of $111 \mathrm{~m}$. Thus, the light levels at these depths were nearly same in late fall and spring. Our measurements show that T. raschii aggregated between 100 and $120 \mathrm{~m}$ during the daytime in both fall and spring cruises. Although estimating the real light level at a given depth is more complicated, our estimate is roughly of the first order, and illustrates that a large change in sea surface irradiance does not result in a similarly large change in the light level at depth, i.e. at the migration depth of $T$. raschii.

Our observations on the vertical migration patterns of euphausiids cannot be described by a simple sinusoid function as has been traditionally done (Ashjian et al. 1998). Euphausiids remained at the bottom or the depth of 100 to $120 \mathrm{~m}$ during the daylight hours. The timing of migration can be calculated using the light cue, although the amount of light may not be important. The upward migration of euphausiids was rapid (within minutes), nearly a step function of time. Their migration to the surface at night should not be interpreted as a function of light, since when there is no light, it should no longer be a factor affecting euphausiid behavior. Their migration should thus simply be driven by a search for food. Their initial upward movement could be to graze on surface phytoplankton. After these had been grazed, the euphausiids dispersed throughout to the whole water column in search of food.

\section{Interaction between zooplankton behavior and currents}

It is presumed that advection of zooplankton by currents determines their transport and distribution at the mesoscale in coastal oceans (Haury 1976, Haury et al. 1992, Huntley et al. 1995). In contrast, the entrapment of zooplankton in estuaries and fjords has been discussed in terms of relatively weak currents, food availability from terrestrial sources, and high productivity induced by nutrient input through terrestrial runoff (Lindahl \& Hernroth 1988, Aksnes et al. 1989). In a southern Norwegian fjord, studies in June and October found that the mesozooplankton did not show any diel vertical migration pattern near the fjord sill (Aksnes et al. 1989), and thus residual currents determined the 1-way transport of mesozooplankton. During our study period, diel vertical migration was one of the dominant behaviors of euphausiids, and complicated the advection processes.

Euphausiids remained at depth from approximately 09:00 to 17:00 h (a short daylight period of $8 \mathrm{~h}$ ), and occupied the upper water column during most of the long dark period (16 $\mathrm{h}$ in our fall survey period). During this season, the buoyancy-driven current displayed a reverse estuarine circulation pattern, i.e. an inflow in the upper layers and an outflow in the deep layers. In both Ullsfjorden and Sørfjorden, euphausiids were advected into the fjords in the upper layer during the fall and winter seasons, because they remained in the upper layer during most of the $24 \mathrm{~h}$ diurnal period (Fig. 10). If we take a mean residual flow of $5 \mathrm{~cm} \mathrm{~s}^{-1}$, the advection of euphausiids could cause a net displacement of $1.4 \mathrm{~km}$ inward in a $24 \mathrm{~h}$ period, assuming that they spent $8 \mathrm{~h}$ in the deep outflow layer, and $16 \mathrm{~h}$ in the upper inflow layer. Migration behavior played a critical role in their net 1-way transport.

Circulation in fjords is similar to that typical for estuarine waters in spring, resulting from strong freshwater runoffs due to increases in both solar radiation and daylight hours. The tidal current in Sørfjorden is relatively weak because of its shallow sill and narrow entrance. The euphausiid distribution over $24 \mathrm{~h}$ in Sørfjorden is shown in Fig. 13. Euphausiids remained at depth from 05:00 to 20:00 $\mathrm{h}(15 \mathrm{~h})$ and in the upper water column for $9 \mathrm{~h}$. At the surface, outflowing currents transported them outward. Downstream, near the shallows, they moved downward because of the arrival of dawn, and near the bottom, they were advected upstream, back to the deep basin. A similar combination of physical and behavioral processes occurred in Ullsfjorden (Fig. 12). Although the outward limits of the euphausiid aggregation were not found (the aggregation was too long to be covered during the available survey time), the effect of differential advection on euphausiid transport was clear.

\section{Swimming characteristics of euphausiids}

An ADCP measures the motion of backscatterers, and at our study sites the dominant backscatterers were euphausiids. Their movements can be either passive (advection by currents) or active (swimming). Taking the size range of a euphausiid as being between 1 and $4 \mathrm{~cm}$, their cruising speed is between approximately 2 and $12 \mathrm{~cm} \mathrm{~s}^{-1}$, which is 2 to 3 times their body length (Kils 1979, 1983), and is on the same order of horizontal current velocities. There is no method currently available for distinguishing between the 2 components, euphausiid horizontal swimming and horizontal current velocity. However, in the vertical direction, average velocity is equal to zero for short 
waves, and is much less than $1 \mathrm{~mm} \mathrm{~s}^{-1}$ for tidal currents, mesoscale eddies and long waves in Ullsfjorden and Sørfjorden (Pedlosky 1987). The swimming velocity of euphausiids surpassed vertical current velocity in ADCP measurements.

The systematic downward velocities in the upper 40 m shown in Figs. 12 \& 13 (bottom graphs) represent euphausiids escaping from our research vessel. Among potential errors for the interpretation of ADCP measurements, asymmetrical pitching and rolling could produce a biased vertical component. Both Ullsfjorden and Sørfjorden are protected from strong winds by surrounding mountains. During most of our survey periods, both fjords were very calm, and pitching and rolling at the ship were negligible. Because the ADCP transducers are mounted at an angle of $30^{\circ}$ relative to the vertical axis, the error of vertical velocity measurements is less than that of horizontal velocity measurements $\left(1.5 \mathrm{~cm} \mathrm{~s}^{-1}\right)$. The vertical component of velocity at a depth of $40 \mathrm{~m}$ could not be produced by water displacement of a ship. We therefore interpret downward velocity components measured by the ADCP in Figs. 12 \& 13 as the downward swimming euphausiids.

In Sørfjorden, downward mean velocity was approximately $4 \pm 2 \mathrm{~cm} \mathrm{~s}^{-1}$ in the presence of euphausiid aggregations (Fig. 13). It is clear that the euphausiids dived away from the ship, but it is not clear in which direction in the horizontal they moved, since the horizontal current velocities surpassed their horizontal swimming velocities in this case. Assuming that euphausiids swim isotropically and that their total velocity is equal to $\left(3 \times w^{2}\right)^{1 / 2}$, where $w$ is the vertical velocity component, then the swimming velocity of euphausiids would be approximately equal to $7 \pm 4 \mathrm{~cm} \mathrm{~s}^{-1}$. On the other hand, if we take an average length of $1.2 \mathrm{~cm}$ for Thysanoessa raschii, their escape velocity would be approximately $7.2 \mathrm{~cm} \mathrm{~s}^{-1}$ (6 times their body length $\mathrm{s}^{-1}$; Kils 1979, 1983). Our measurements are very close to this theoretical estimate.

Meganyctiphanes norvegica were bigger, and stronger swimmers than Thysanoessa raschii in Ullsfjorden, and did not migrate below $50 \mathrm{~m}$ during our surveys (Fig. 12). When T. raschii aggregations remained at depth during the day, their mean vertical velocity in the upper $50 \mathrm{~m}$ was approximately $5 \pm 3 \mathrm{~cm} \mathrm{~s}^{-1}$, and when they stayed in the upper layer, their mean vertical velocity in the upper $50 \mathrm{~m}$ was reduced to approximately $3 \pm 3 \mathrm{~cm} \mathrm{~s}^{-1}$. Therefore, the vertical velocity of $5 \pm 3 \mathrm{~cm} \mathrm{~s}^{-1}$ was contributed by $M$. norvegica only. The mean swimming velocity of $M$. norvegica was thus approximately $9 \pm 6 \mathrm{~cm} \mathrm{~s}^{-1}$.

The vertical distance within which euphausiids responded to the ship was approximately $40 \mathrm{~m}$ (Figs. 12 \& 13). Below this depth, the vertical component in ADCP velocity measurements was insignificant. The
ADCP was mounted approximately $9 \mathrm{~m}$ behind the bow of the RV 'Johan Ruud', which we used for these 2 surveys. If we assume that euphausiid aggregations would not be disturbed until the ship's bow was above them, and the ship was traveling at approximately $3 \mathrm{~m} \mathrm{~s}^{-1}$, then the ship would travel $9 \mathrm{~m}$ in $3 \mathrm{~s}$ from the arrival of the bow at the euphausiid swarm to the arrival of the ADCP. If euphausiids $40 \mathrm{~m}$ away responded to ship's arrival within these $3 \mathrm{~s}$, then any warning must travel in a euphausiid aggregation at a speed faster than $13 \mathrm{~m} \mathrm{~s}^{-1}$. We do not know what form any such warning takes, and $13 \mathrm{~m} \mathrm{~s}^{-1}$ may be an overestimate, since a warning could also travel forward so that euphausiids respond earlier. Horizontal transmission of a warning between euphausiids might not necessarily cause coherent downward movement of euphausiids, and such downward movement might not start until the arrival of the ship. Thus, a warning traveling speed of $13 \mathrm{~m} \mathrm{~s}^{-1}$ is a conservative estimate.

The vertical velocity measurements imply that euphausiids may respond to a vessel within a distance of $40 \mathrm{~m}$ at a relaying speed $>13 \mathrm{~m} \mathrm{~s}^{-1}$; this illustrates the avoidance capacity of euphausiids during a net tow. To increase catch efficiency, the sampling method must either be faster than the relaying speed of euphausiids, or the sampling devices must not be visible to the euphausiids. Towing nets at night and/or from below at fast speed are typical ways in which to improve sampling efficiency by reducing the visibility of nets.

The aggregation behavior of marine organisms is directly related to their random movements (Okubo 1980, 1986, Zhou \& Huntley 1996). However, except for large fishes and mammals, in situ observations of marine organisms have been restricted by a lack of technology. The Doppler spectra for studying the body movements of fishes and schooling behavior was first used by Holliday $(1974,1977)$, and then by Zhou \& Huntley (1996) and Demer et al. (2002). The present study has extended Doppler technology to studies of spatial variation in behavior within marine organism aggregations. Fig. 16 shows a $24 \mathrm{~h}$ time series of vertical profiles of both volume backscattering, converted to ind. $\mathrm{m}^{-3}$ (assuming a mean size of $1.2 \mathrm{~cm}$ for Thysanoessa raschii) and a spectrum width anomaly in $\mathrm{cm} \mathrm{s}^{-1}$ (obtained by subtracting a grand mean from the spectrum width measurements) at Stn 6, which illustrate both euphausiid aggregations and their randomness. The grand mean of spectrum width measurements represents the background turbulence level and finite pulse length. The negative spectrum width anomaly was produced by backscatterers with less randomness, who were strong swimmers capable of overcoming background turbulence to maintain their position (i.e. schooling behavior), the positive anomaly represents the additional random movement contributed by 
those backscatterers who swim randomly during either feeding or aggregation.

The diel migration study began around 11:00 h during the spring cruise in April. Thysanoessa raschii remained at the bottom (Fig. 16). The yellow layer in Fig. 16 is centered at approximately $30 \mathrm{~m}$, with a negative spectrum width anomaly. Net tow samples revealed that no euphausiid species contributed to this backscattering layer. Other Thysanoessa species were few, and migrated vertically together with $T$. raschii; Meganyctiphanes norvegica was absent from our net tow samples in Sørfjorden; Calanus finmarchicus was numerically abundant, with a surface maximum; Sagitta elegans was also abundant, with a bottom maximum. None of these species from our net tow samples could have been responsible for this acoustic layer. Several hypotheses can be made. For example, the herring Clupea harengus, which was abundant in the fjords and whose schooling behavior is well-documented, could have been responsible for this layer. Alternatively, $M$. norvegica, which is very mobile, and whose acoustic patterns in Ullsfjorden were very similar to those in Sørfjorden, could have been responsible. This low random movement layer disappeared when $T$. raschii migrated to the upper layer at night, and reappeared after $T$. raschii descended to the bottom at dawn.

The Thysanoessa raschii aggregation rose to the surface at 20:00 $\mathrm{h}$ around sunset during the spring cruise. The anomaly in the spectrum width measurements indicates the degree of random movement: positive values at the edge of an aggregation represent stronger random movement, negative values inside an aggregation less random movement. Such random movement patterns persisted thoughout the night until their descent at dawn. Immediately, after their ascent at sunset, maxima in abundance appeared, one at the surface and one centered around $60 \mathrm{~m}$. This division was also seen in other surveys (Figs. $9 \& 13$ ). The surface aggregation displayed positive values for the spectrum width anomaly, representing strong random swimming; and the deep aggregation had negative values, representing less random swimming.

\section{Euphausiid aggregation dynamics}

Euphausiid aggregations were present in both Ullsfjorden and Sørfjorden throughout our survey periods, and probably between surveys. Although the net influx of euphausiids resulted from a combination of current circulation patterns and diel vertical migration, behavioral factors maintained them in aggregations. The aggregations of euphausiids in Ullsfjorden and the inner basin of Sørfjorden were surveyed several times over a diurnal period to illustrate the evolution of euphausiid aggregations during vertical migration (Figs. 4 \& 12-14).

The density of euphausiids in an aggregation varied: during the day they formed a relatively thin very dense layer of $>100$ to 1000 ind. $\mathrm{m}^{-3}$, and remained immediately above the bottom or at depths $>100$ to $120 \mathrm{~m}$. Before sunset, they moved into the upper water column as a less compact layer. During the night, they formed a layer of $>10$ to 100 ind. $\mathrm{m}^{-3}$, being relatively less dense at the surface. Because of diel variation in the density of euphausiids, the vertical thickness of a euphausiid layer was thinner (approximately $40 \mathrm{~m}$ ) during the day, and (thicker approximately $80 \mathrm{~m}$ ) at night (Figs. 12 \& 13). A similar change in aggregation behavior of Euphausia superba was also observed in other studies in the Southern Ocean (Zhou \& Dorland 2004).

Because there is a certain amount of randomness in euphausiid movements, their aggregation mechanism and patch dynamics have been studied as stochastic processes (Okubo 1980, 1986, Anderson 1981). Under stochastic theory, the random motion of euphausiids contributes to a diffusion process, which is counterbalanced by deterministic swimming against the diffusion. Thus, a euphausiid would stochastically swim towards the less dense side of an aggregation, and then deterministically swim back. We apply this concept to the edges of euphausiid aggregations in Sørfjorden, specifically to the bottom edge of an aggregation.

Starting with the standard definition of a diffusion coefficient (Taylor 1921, Davis 1991), the vertical diffusion coefficient $\left(A_{\mathrm{z}}\right)$ of euphausiids is

$$
A_{z}=\lim _{t \rightarrow \infty}\left[w^{\prime}\left(t_{0} \mid z, t_{0}\right) z^{\prime}\left(t_{0}-t \mid z, t_{0}\right)\right]
$$

where the square brackets are the ensemble average, $w^{\prime}$ and $z^{\prime}$ are random swimming and displacement of a euphausiid, respectively, $z$ is the location of the euphausiid at Time $t_{0}$, and $t$ is time. The notation of $w^{\prime}\left(t \mid z, t_{0}\right)$ is the value $w^{\prime}(t)$ of the euphausiid passing through $z$ at Time $t_{0}$. In our case, because a euphausiid swims as far as the edge of an aggregation, the largest scale of the random displacement would be equal to the spatial scale of the abundance gradient at the edge of an aggregation. Thus, we have $\left[A_{z}\right]=\left[w^{\prime}\right]\left[z^{\prime}\right]$, where the square brackets indicate the scale of a variable. The spatial scale of a strong gradient at the aggregation edge is approximately $10 \mathrm{~m}$ (Fig. 13). The euphausiids' random swimming velocities are approximately $5 \mathrm{~cm} \mathrm{~s}^{-1}$ (Fig. 16). If we assume $\left[w^{\prime}\right]=5 \mathrm{~cm} \mathrm{~s}^{-1}$ and $\left[z^{\prime}\right]=10 \mathrm{~m}$, we obtain $\left[A_{z}\right]=5 \times 10^{3} \mathrm{~cm}^{2} \mathrm{~s}^{-1}$. Mixing of euphausiids produced by their random swimming is 10 to 100 times greater than mixing due to turbulence.

The hypothesis of a balance between stochastic movement and deterministic swimming can be expressed by the advection and diffusion equation in 
the vertical direction in a steady state (Okubo 1980, 1986, Anderson 1981):

$$
w_{e} \frac{\partial C}{\partial z}=\frac{\partial}{\partial z}\left(A_{z} \frac{\partial C}{\partial z}\right)
$$

where $W_{\mathrm{e}}$ is the mean deterministic swimming velocity against diffusion, $C$ is euphausiid abundance, $z$ is the vertical axis, and $A_{z}$ is the diffusion coefficient due to random movement. From the scaling analysis of Eq. (6), the order of $w_{\mathrm{e}}$ should be equal to $\left[A_{z}\right] /\left[z^{\prime}\right]$. Thus, we have $\left[w_{\mathrm{e}}\right]=\left[w^{\prime}\right]$, which means that deterministic swimming should be equivalent to stochastic wandering, so that the net effect would be counterbalanced. If this were true, we should be able to measure the deterministic swimming velocity $\left(w_{\mathrm{e}}\right)$ at the edge of a euphausiid aggregation, which is approximately $5 \mathrm{~cm} \mathrm{~s}^{-1}$. Our measurements show no such aggregation vertical velocity at the bottom or top edge of aggregations (Figs. $12 \& 13$ ). Without this deterministic vertical velocity, the random velocities would not be counterbalanced, which would then lead to a quick dispersion based on stochastic theory. However, euphausiids were strongly aggregated.

This mismatch between the theoretical conclusion and observations led us take a new look at the configuration and logic of the existing theory. Taking an experiment consisting of a euphausiid aggregation in a steady state, we follow a euphausiid to record how it moves. The euphausiid swims out of the aggregation by random movement, and swims towards the aggregation as aggregative behavior. The mean effect on the aggregation is counteracted; i.e. the mean swimming velocity is equal to zero. Now we choose a control volume, and measure the velocities of all euphausiids. The sum of all velocity measurements is the mean swimming velocity of all euphausiids in the control volume, regardless of whether some are swimming outward in random movement or swimming inward in aggregation behavior. In a steady state, the net flux of euphausiids into a control volume should be equal to zero, i.e. the mean swimming velocity is equal to zero. Therefore, when a euphausiid aggregation forms at the surface or bottom, and is in an almost steady state, the mean velocities relative to the aggregation must vanish. But can euphausiids maintain both stochastically random movement and aggregation without being dispersed when the mean velocities vanish? The answer is a conditional yes. When an aggregation reaches a steady state, all slots have been assigned to individual euphausiids. The exchange between slots has to be done by one to one, which is independent of the gradient of the distribution of euphausiids. An exchange can be random, but the net effect on velocity and distribution will be nullified by the one to one relation. Such random movement will not produce a diffusion effect.

\section{CONCLUSIONS}

This study examined the spatial and temporal variations in physical processes and behavior of zooplankton at scales from hours to seasons and from 10s to $1000 \mathrm{~s}$ of $\mathrm{m}$, using a suite of instruments including ADCP, CTD and a fluorometer. The high resolution, repeated measurements from our 2 cruises have not only revealed the semidiurnal tidal currents in both Ullsfjorden and Sørfjorden, seasonal baroclinic circulation, and spatiotemporal structures of daily migrating aggregations of euphausiids, but have also enabled us to better understand how these physical and behavioral processes, which determine the transport and distribution of euphausiids in these fjords, are coupled. The results revealed that seasonal changes in buoyancy forcing produced by freshwater runoff in spring, and by surface cooling and ice formation in fall and winter, determine the seasonal changes in circulation and water exchange between fjords and adjacent shelf waters. In response to these seasonal changes in the physical environment, the migration pattern of euphausiids changes as a function of seasonal daily insolation. Covariation in these physical and biological processes leads to net transport of euphausiids into fjords in fall, winter and spring. In the fall and winter, euphausiids are transported into fjords by inward-bound surface currents produced by surface cooling and ice formation, while euphausiids remain in the upper water column during the long night hours. In the spring, euphausiids remained at depth during the long hours of daylight, and are transported into the fjord by the inward-bound bottom current. Our study also examined the kinematics of euphausiid aggregations. Measurements of euphausiid swimming velocities indicate that they are capable of swimming at $>6$ body lengths $\mathrm{s}^{-1}$ in response to the presence of a research vessel. The response to the presence of a vessel travelled through euphausiid aggregations up to a distance of $40 \mathrm{~m}$ at a relaying speed of $>10 \mathrm{~m} \mathrm{~s}^{-1}$. Within an aggregation, the relative velocity of euphausiids in the center is low, within the measurement error of $1 \mathrm{~cm} \mathrm{~s}^{-1}$; this implies a balance between the aggregative tendency at the center of an aggregation and the gradients of euphausiid abundance. Euphausiids can aggregate and remain aggregated within strong current fields mainly by means of strong swimming and aggregation behavior. When an aggregation reaches steady state, random movement occurs, but exchanging positions between euphausiids has to be coordinated between individuals. Such random movement will not produce a diffusion effect.

Acknowledgements. This research was supported by NSF grants OPP-9423329 and OPP-9906575 to M.Z. We thank the crews on RV 'Johan Ruud' and 'Jan Mayen' for all their help 
during the cruises. M.Z. would like to give special thanks to Dr. M. E. Huntley for his encouragement to develop new concepts and methods, and to execute the project. Thanks also to Dr. W. Nordhausen for his assistance and collaboration and Dr. X. Zhong for his assistance in field and laboratory work.

\section{LITERATURE CITED}

Aksnes DL, Aure J, Kaartvedt S, Magnesen T, Richard J (1989) Significance of advection for the carrying capacities of fjord populations. Mar Ecol Prog Ser 50:263-274

Anderson JJ (1981) A stochastic model for the size of fish schools. Fish Bull Fish Wildl Serv US 19:315-323

Ashjian CJ, Sharon LS, Flagg CN, Wilson C (1998) Patterns and occurrence of diel vertical migration of zooplankton biomass in the Mid-Atlantic Bight described by an Acoustic Doppler Current Profiler. Cont Shelf Res 18: 831-858

Brierley AS, Brandon MA, Watkins JL (1998) An assessment of the utility of an acoustic Doppler Current profiler for biomass estimation. Deep-Sea Res 45:1555-1573

Brooks ER, Mullin MM (1983) Diel changes in the vertical distribution of biomass and species in the Southern California Bight. Calif Coop Ocean Fish Investig Rep 24:210-215

Cushing DH (1951) The vertical migration of planktonic crustacea. Biol Rev 26:158-192

Davis RE (1991) Observing the general circulation with floats. Deep-Sea Res 38(Suppl 1):S531-S571

Demer DA, Conti SG (2003) Reconciling theoretical versus empirical target strength of krill: effects of phase variability on the distorted-wave born approximation. ICES J Mar Sci 60:429-434

Demer D, Hewitt R (1995) Bias in acoustic biomass estimates of Euphausia superba due to diel vertical migration. DeepSea Res I 42:455-475

Demer DA, Martin LV (1995) Zooplankton target strength: volumetric or aerial dependence? J Acoust Soc Am 92: $1111-1118$

Demer DA, Barange M, Boyd AJ (2002) Measurements of three-dimensional fish school velocities with an acoustic Doppler current profiler. Fish Res 47:201-214

Dyer KR (1997) Estuaries. John Wiley \& Sons, Chichester

Falkenhaug T, Tande KS, Timonin A (1997) Spatio-temporal patterns in the copepod community in Malangen, northern Norway. J Plankton Res 19:449-468

Falk-Petersen S (1985) Growth of the euphausiids Thysanoessa inermis, Thysanoessa raschii, and Meganyctiphanes norvegica in a subarctic fjord, North Norway. Can J Fish Aquat Sci 42:14-22

Falk-Petersen S, Hopkins CCE (1981) Zooplankton sound scattering layers in north Norwegian fjords: interactions between fish and krill shoals in a winter situation in Ullsfjorden and Oksfjorden. Kiel Meeresforsch 5:191-201

Flagg CN, Smith SL (1989a) Zooplankton abundance measurements from acoustic Doppler current profilers. Oceans '89, Marine Technology Society, Institute of Electrical and Electronics Engineers, Seattle, WA

Flagg CN, Smith SL (1989b) On the use of the acoustic Doppler current profiler to measure zooplankton abundance. Deep-Sea Res 36:455-474

Greenlaw CF (1977) Backscattering spectra of preserved zooplankton. J Acoust Soc Am 62:44-52

Gupta S, Lonsdale D, Wang DP (1994) The recruitment of an estuarine copepod: a biological-physical model. J Mar Res 52:687-710

Hamner WH, Hamner PP, Strand SW, Gilmer RW (1983)
Behavior of Antarctic krill, Euphausia superba: chemoreception, feeding, schooling and moulting. Science 220: 433-435

Hamner WM, Hamner PP, Obst BS, Carleton JH (1989) Field observations on the ontogeny of schooling of Euphausia superba furciliae and its relationship to ice in Antarctic waters. Limnol Oceanogr 34:451-456

Harris RP, Wiebe PH, Lenz J, Skjoldal HR, Huntley M (2000) ICES zooplankton methodology manual. Academic Press, London

Haury LR (1976) Small-scale pattern of a California Current assemblage. Mar Biol 37:137-157

Haury LR (1984) An offshore eddy in the California Current system. Part IV. Plankton distributions. Prog Oceanogr 13: 95-111

Haury LR, Yamazaki H, Fey CL (1992) Simultaneous measurements of small-scale physical dynamics and zooplankton distributions. J Plankton Res 14:513-530

Holliday DV (1974) Doppler structure in echoes from schools of pelagic fish. J Acoust Soc Am 55:1313-1322

Holliday DV (1977) Two applications of the Doppler effect in the study of fish schools. Rapp PV Cons Perm Int Explor Mer 170:21-30

Hopkins CCE, Falk-Petersen S, Tande K, Eilertsen HC (1978) A preliminary study of zooplankton sound scattering layers in Balsfjorden: structure, energetics, and migrations. Sarsia 63:255-264

Hopkins CCE, Tande KS, Grönvik S, Sargent JR (1984) Ecological investigations of the zooplankton community of Balsfjorden, northern Norway: an analysis of growth and overwintering tactics in relation to niche and environment in Metridia longa (Lubbock), Calanus finmarchicus (Gunnerus), Thysanoessa inermis (Kröyer), and T. raschii (M. Sars). J Exp Mar Biol Ecol 82:77-99

Huntley ME, Zhou M, Nordhausen W (1995) Mesoscale distribution of zooplankton in the California Current in late spring, observed by optical plankton counter. J Mar Res 53:647-674

Kaartvedt S, Svendsen H (1995) Effect of freshwater discharge, intrusions of coastal water, and bathymetry on zooplankton distribution in a Norwegian fjord system. J Plankton Res 17:493-511

Kalinowski J (1978) Vertical migration of krill in the region of South Georgia, February-March, 1976. Pol Arch Hydrobiol 25:573-583

Kils U (1979) Swimming speed and escape capacity of Antarctic krill, Euphausia superba. Meeresforschung 27:264-266

Kils U (1983) Swimming and feeding of Antarctic krill, Euphausia superba-some outstanding energetics and dynamics - some unique morphological details. Ber Polarforsch 4:130-155

Kirk JTO (1983) Light and photosynthesis in aquatic ecosystems. Cambridge University Press, London

Lindahl O, Hernroth L (1988) Large-scale and long-term variations in the zooplankton community of the Gullmar fjord, Sweden, in relation to advective processes. Mar Ecol Prog Ser 43:161-171

Ljøen R (1962) The waters of the western and northern coast of Norway in July-August 1957. Fiskeridir Skr Ser Havunders 13:1-39

Mackas DL, Washburn L, Smith SL (1991) Zooplankton community pattern associated with a California Current cold filament. J Geophys Res 96:14781-14797

McGehee DE, O'Driscoll RL, Martin Traykovski LV (1998) Effect of orientation on acoustic scattering from Antarctic krill at $120 \mathrm{kHz}$. Deep-Sea Res 45:1273-1294

Ohman MD, Frost BW, Cohen M (1983) Reverse diel vertical 
migration: an escape from vertebrate predators. Science 220:1404-1407

Okubo A (1980) Diffusion and ecological problems: mathematical models, biomathematics. Springer-Verlag, Berlin

Okubo A (1986) Dynamical aspects of animal swarming: swarms, schools, flocks and herds. Adv Biophys 22:1-94

Partridge BL (1982) The structure and function of fish schools. Am Sci 246:90-99

Pedlosky J (1987) Geophysical fluid dynamics. SpringerVerlag, New York

RD Instruments (1989) Acoustic Doppler current profilers. Principles of operation: a practical primer. RD Instruments, San Diego, CA

RD Instruments (1990) Calculating absolute backscatter. Technical Bulletin ADCP-90-04. RD Instruments, San Diego, CA

Ringelberg J, Flik BJG, Lindenaar D, Royackers K (1991) Diel vertical migration of Daphnia hyalina (sensu latiori) in Lake Maarsseveen. Part 1. Aspects of seasonal and daily timing. Arch Hydrobiol 121:129-145

Tande KS (1982) Ecological investigations on the zooplankton community of Balsfjorden, northern Norway: generation cycles, and variations in body weight and body content of carbon and nitrogen related to overwintering and reproduction in the copepod Calanus finmarchicus (Gunnerus). J Exp Mar Biol Ecol 62:129-142

Tande KS, Slagstad S (1982) Ecological investigation on the zooplankton community of Balsfjorden, northern Norway. Seasonal and short-time variations in enzyme activity in copepodite Stage V and VI males and females of Calanus finmarchicus (Gunnerus). Sarsia 67:63-68

Editorial responsibility: Otto Kinne (Editor-in-Chief), Oldendorf/Luhe, Germany
Tarling GA, Matthews JBL, David P, Guerin O, Buchholz F (2001) The swarm dynamics of northern krill (Meganyctiphanes norvegica) and pteropods (Cavolinia inflexa) during vertical migration in the Ligurian Sea observed by an acoustic Doppler current profiler. Deep-Sea Res I 48: 1671-1686

Tarling GA, Jarvis T, Emsley SM, Matthews JB (2002) Midnight sinking behaviour in Calanus finmarchicus: a response to satiation or krill predation? Mar Ecol Prog Ser 240:183-194

Taylor GI (1921) Diffusion by continuous movements. Proc Lond Math Soc 20:165-212

Wiebe PH, Burt KH, Boyd SH, Morton AW (1976) A multiple opening-closing net and environmental sensing system for sampling zooplankton. J Mar Res 34:313-325

Zhou M (1998a) Influence of bottom stress on the two-layer flow induced by gravity currents in estuaries. Estuar Coast Shelf Sci 46:811-825

Zhou M (1998b) An objective interpolation method for spatiotemporal distribution of marine plankton. Mar Ecol Prog Ser 174:197-206

Zhou M, Dorland RD (2004) Aggregation and vertical migration behavior of Euphausia superba. Deep-Sea Res II 51: $2118-2138$

Zhou M, Huntley ME (1996) The principle of biological attraction, demonstrated by the bio-continuum theory of zooplankton patch dynamics. J Mar Res 54:1017-1037

Zhou M, Nordhausen W, Huntley ME (1994) ADCP measurements of the distribution and abundance of euphausiids near the Antarctic Peninsula in winter. Deep-Sea Res I 41: $1425-1445$

Submitted: February 21, 2003; Accepted: October 21, 2004 Proofs received from author(s): July 4, 2005 